\title{
The Neuroscience of Intergroup Relations
}

\section{Citation}

Cikara, Mina, and Jay J. Van Bavel. 2014. "The Neuroscience of Intergroup Relations."

Perspectives on Psychological Science 9 (3) (May): 245-274. doi:10.1177/1745691614527464.

\section{Published Version}

doi:10.1177/1745691614527464

\section{Permanent link}

http://nrs.harvard.edu/urn-3:HUL.InstRepos:34565389

\section{Terms of Use}

This article was downloaded from Harvard University's DASH repository, and is made available under the terms and conditions applicable to Other Posted Material, as set forth at http:// nrs.harvard.edu/urn-3:HUL.InstRepos:dash.current.terms-of-use\#LAA

\section{Share Your Story}

The Harvard community has made this article openly available.

Please share how this access benefits you. Submit a story.

\section{Accessibility}




\section{Running head: THE NEUROSCIENCE OF INTERGROUP RELATIONS}

The neuroscience of intergroup relations:

An integrative review

Mina Cikara*

Carnegie Mellon University

Jay J. Van Bavel*

New York University

Main text word count: 13,253

* Authors made equal contributions.

Dr. Mina Cikara

Assistant Professor

Department of Social and Decision Sciences

Carnegie Mellon University

5000 Forbes Ave

Pittsburgh, PA 15213

Tel: (412) 268-4480

Fax: (412) 268-6938

mcikara@andrew.cmu.edu 


\begin{abstract}
We review emerging research on the psychological and biological factors that underlie social group formation, cooperation, and conflict in humans. Our aim is to integrate the intergroup neuroscience literature with classic theories of group processes and intergroup relations in an effort to move beyond merely describing the effects of specific social out-groups on the brain and behavior. Instead, we emphasize the underlying psychological processes that govern intergroup interactions more generally: forming and updating our representations of "us" and "them" via social identification and functional relations between groups. This approach highlights the dynamic nature of social identity and the context dependent nature of intergroup relations. We argue that this theoretical integration can help reconcile seemingly discrepant findings in the literature, provide organizational principles for understanding the core elements of intergroup dynamics, and highlight several exciting directions for future research at the interface of intergroup relations and neuroscience. (146 words)
\end{abstract}




\section{The neuroscience of intergroup relations:}

\section{An integrative review}

The human brain is "truly social", which is to say specialized for group living (Caporeal, 1997; Dunbar, 1998). People who accurately identify, value, and cooperate with in-group members enjoy numerous benefits, including the fulfillment of many basic psychological needs (Allport, 1954; Correll \& Park, 2005; Kurzban \& Neuberg, 2005; Wilson \& Wilson, 2007). The value humans place on group membership is illustrated by the ease with which humans form groups and favor in-group members. The propensity to prefer one's in-group has been observed in every culture on earth (Brown, 1991) and in children as young as five (Dunham et al., 2011; Fehr, Bernhard, \& Rockenbach, 2008). Extensive research has shown that even arbitrary assignment to a group elicits preferences for in-group relative to out-group members across a wide variety of indices, and does so in the absence of factors typically thought to account for intergroup discrimination, such as prior contact with in-group or out-group members and competition over resources (Tajfel, 1970).

The functional benefits of group membership notwithstanding, group life is also a source of social strife and destruction (e.g., pressure to conform within groups, protracted conflict between groups; Brewer, 1999; Cosmides, 1989; Hewstone et al., 2002; Neuberg \& Cottrell, 2006). Intergroup conflict, in particular, has been described as "one of the greatest problems facing the world today" (Cohen \& Insko, 2008). For example, it has been estimated that over 200 million people were killed in the last century due to genocide, war, and other forms of group conflict (Woolf \& Hulsizer, 2004). The social and economic obstacles of group living have attracted the attention of scholars and scientists from social, developmental, evolutionary, and cognitive psychology, social neuroscience, biological and cultural anthropology, among others. 
In the last few decades, there has been a surge of interest in the effects of group membership on basic perceptual, cognitive, and biological processes with the goal of better understanding how these processes, in turn, contribute to parochialism, prejudice, and intergroup conflict. This interdisciplinary approach - termed social neuroscience (Cacioppo, Berntson, Sheridan, \& McClintock, 2000) or social cognitive neuroscience (Ochsner and Lieberman, 2001) - to the study of intergroup relations has captured the attention of the scientific community (e.g., Kubota et al, 2012; Molenberghs, 2013), as well as the popular media and society more broadly (e.g., Brooks, New York Times, 9/12/09). This approach builds on the assumption that complex social phenomena, such as intergroup relations, may be better understood by combining social and biological theories and methods that traverse multiple-levels of analysis (Cacioppo \& Cacioppo, 2013). Researchers in this area have already helped to bolster and refine existing psychological theories of intergroup relations (e.g., Derks, Scheepers, \& Ellemers, 2013), highlighted the contextual flexibility of seemingly "hard-wired" biological responses (e.g., Wheeler \& Fiske, 2007; Van Bavel, Packer, \& Cunningham, 2008), and challenged popular interpretations of biological systems (e.g., De Dreu et al., 2011). In the domain of intergroup relations, this approach may ultimately inform the design of better targeted interventions (including pharmacological interventions) for mitigating prejudice and intergroup conflict (e.g., Terbeck et al., 2012).

To date, intergroup and cultural neuroscience has largely focused on specific social groups rather than studying the dynamics that govern group formation and intergroup interactions. Several excellent reviews have examined the neural basis of social categorization along boundaries marked by visual cues to targets' group membership, such as race, sex, and age (e.g., Eberhardt, 2005; Ito \& Bartholow, 2009; Kubota et al., 2012); however, broader inferences 
about group processes are often difficult to make on the basis of these social categories due to confounding variables (e.g., differences in the visual appearance of target stimuli, associated stereotypes and prejudices, and perceivers' personal experience with groups in question). Furthermore, research that focuses exclusively on a single, static category boundary fails to account fully for the flexible nature of social identity representation (e.g., the effects of context on self-categorization, the effects of task on person construal; Freeman \& Ambady, 2011). Thus, the next phase of intergroup neuroscience research must account for the fact that not all outgroups are equivalent, not all group memberships are static, and which group identities are salient is highly context dependent (Turner, Oakes, Haslam, \& McGarty, 1994).

We therefore focus our attention on research examining (1) how the basic concepts of "us" and "them" are represented in the mind and brain and (2) the factors that drive people to flexibly update these representations: social identity (Tajfel \& Turner, 1979; Turner et al., 1987), cooperation (Deutsch, 1949), and competition (Sherif et al., 1961). Building on these classic perspectives, we emphasize the processes by which social groups are defined (e.g., selfcategorization, common fate) as well as the forces that intensify group identities and intergroup conflict (shared versus competing goals, status threat). We argue that focusing on these elemental features, rather than specific, static social groups in isolation, will help to resolve seemingly discrepant findings in the emerging literature, generate novel hypotheses, and offer a more general framework for understanding the neuroscience of intergroup relations.

\section{Overview}

In order to integrate major theories of intergroup relations with research on the neural systems implicated in maintaining and updating our representations of in-group and out-group members, we examine how these representations affect fundamental psychological processes 
including perception, emotion, motivation, and decision-making, as well as subsequent behavior. We also review some of the scientific advantages of assigning people to novel groups (Tajfel, Billig, Bundy, \& Flament, 1971) and manipulating group features and intergroup dynamics. To illustrate the utility of this approach, we highlight occasions on which studying intergroup phenomena in the context of novel groups has incited a revision of existing psychological and neuroscience theories. Our hope is that this approach can better account for findings across multiple contexts and levels of analysis.

We begin by reviewing the influence of social identity and self-categorization on the biological bases of group formation and evaluation. We describe how people move from categorizing themselves as individuals to identifying with a group and representing others as "us" versus "them." We then review the social forces that unite and divide groups, with a specific emphasis on functional relations between groups, relative group status, and the effects of these dynamics on empathy and social behavior (i.e., help, harm). Finally, we outline an agenda for future research to address gaps in this growing area of inquiry and to foster greater collaboration between psychologists and neuroscientists.

\section{REPRESENTING “US” AND “THEM"}

Psychologists have long conceded that prejudice may be an inevitable aspect of human life (Allport, 1954). Categorizing people into social groups - termed social categorization allows us to simplify the social world and generalize our existing knowledge about certain groups and new people (Bruner, 1957). Although social categorization serves an important cognitive function, it can also lead to the activation and application of inaccurate stereotypes and prejudices, unless people are able to individuate specific social targets (Brewer 1988; Fiske \& Neuberg, 1990). As many models of person perception posit, this problem is magnified by the 
fact that the process of categorizing others according to their age, gender, or race can be reflexive and difficult to override (Brewer, 1988; Devine, 1989; Ito \& Urland, 2005; Macrae \& Bodenhausen, 2000; Taylor, Fiske, Etcoff, \& Ruderman, 1978). To help understand how people perceive and evaluate targets from different social categories, scientists have used neuroimaging and other psychophysiological methods to examine how social categories are represented, evaluated, and integrated with ongoing psychological processes (see Amodio, 2008;

Cunningham \& Van Bavel, 2009; Eberhardt, 2005; Ito \& Barthalow, 2009; Kubota et al., 2012; Phelps \& Thomas, 2003; Wheeler \& Fiske, 2005).

This relatively recent application of neuroscience to the study of social categorization has already provided important insights into the specific component processes that underlie intergroup categorization (e.g., Golby, Gabrieli, Chiao, \& Eberhardt, 2001), evaluation (e.g., Phelps et al., 2000), and motivation (e.g., Amodio et al., 2004), and illuminated the time course of intergroup processing (e.g., Cunningham, Van Bavel, Arbuckle, Packer, \& Waggoner, 2012; Ito \& Urland, 2003, 2005). Social group memberships do indeed impact neural processes automatically and unconsciously and these processes have important implications for discriminatory behavior (Cunningham et al., 2004).

Most research that has examined the neural bases of social categorization has focused on static social groups and categories, such as race, rendering the findings ecologically valid, but inferences about the underlying process difficult to generalize. Differences in the groups, context, and the experimental method have often produced inconsistent results. These inconsistencies reflect the fact that race and other social categories are confounded with a variety of factors that might affect neural responses. For instance, participants in previous neuroimaging studies of social categorization often have strong associations with existing social groups, introducing the 
possibility that factors ranging from low-level visual features of stimuli (e.g., luminance and contrast) to novelty, or exposure to stereotypes, can account for differences in neural responses to same versus specific other-race targets. Furthermore, most studies examine how majority group members respond to minority group members; relatively few have directly compared the responses of members of different racial groups to same versus other-race targets within a single study (c.f., Hart et al., 2001; Golby et al, 2001; Lieberman et al., 2005).

In this section, we introduce a different approach to studying the biological bases of group processes. We review self-categorization and social identity theory to explain how people develop and maintain representations of "us" and "them," in the real world and in the laboratory. We then contrast early findings from intergroup neuroscience research (using existing social groups) against more recent findings, which have generated significant re-interpretation of earlier results by incorporating novel groups and classic theories of intergroup relations. We believe this approach complements research with existing social groups by emphasizing the contextdependent nature of social identity representation and identifying organizational principles for understanding the core elements of group formation and evaluation.

\section{Self-categorization, social identity, and minimal groups}

There is no doubt that certain social categories, such as age, gender, and race, play a major role in shaping neural responses as well as the biases and stereotypes that people bring to bear on their social judgments and behavior. However, work on Social Identity Theory (Tajfel \& Turner, 1979) and Self-Categorization Theory (Turner et al., 1987) has argued that how people categorize themselves as members of a group is also fundamental to understanding intergroup relations. Tajfel and Turner conceptualized a group as "a collection of individuals who perceive themselves to be members of the same social category, share some emotional involvement in this 
common definition of themselves, and achieve some degree of social consensus about the evaluation of their group and their membership of it" (1979, p. 40). From this perspective, aggregates of individuals become meaningful social groups by virtue of the fact that the members choose to identify with groups and their other members (see Sherif, 1967).

When people categorize themselves as part of a group or coalition, their self-concept shifts from the individual ("I" or "me") to the collective level ("us" or "we") - a process termed social identification (Brewer, 1996). Social identities represent individuals' knowledge that they belong to certain groups, along with the psychological significance of these groups, their relationship to these groups and group-members, and the associations they have with these groups (Tajfel, 1982). As such, they fulfill a number of basic human motives, including belonging (Brewer, 1991), self-esteem (Tajfel \& Turner, 1979), and certainty (Hogg, 2000) needs.

The act of categorizing one's self as a group member has a significant influence on intergroup perception, evaluation, and behaviors (e.g., Ashburn-Nardo, Voils, \& Monteith, 2001; Otten \& Wentura, 1999; Van Bavel \& Cunningham, 2009, 2011). The nature of the effects depends on which social identity is made salient, which is determined in large part by the social context. Social identities become more inclusive as the context makes more abstract identities salient (e.g., shifting from local to national to global identities), leading to the inclusion of others who would otherwise be deemed as distinct from the self (Gaertner, Mann, Murrell, \& Dovidio, 1989; Turner et al., 1994). On the other hand, the social context can heighten the accessibility of a more specific social identity (e.g., university affiliation, sports team allegiance, etc.), which in turn elicits perceptions and evaluations consistent with the activated aspects of this identity. Specific identities can become integrated with the representation of one's self (Smith \& Henry, 
1996), especially among people who strongly identify with the in-group (Brewer \& Pickett, 1999). Identification with specific groups may even override automatic responses to orthogonal categories like race (Van Bavel \& Cunningham, 2009). In other words, when people identify with a group, their in-group members may be seen as valuable regardless of their race or other seemingly important category memberships.

One important consequence of the social identification process is that humans reliably divide the world into $u s$ and everyone else: them. The mere act of categorizing people into groups has profound implications for intergroup preferences (Brewer, 1979). Group membership matters because it reliably predicts intergroup bias: prejudice and discriminatory behavior that favors the in-group relative to an out-group (Hewstone et al., 2002). Perhaps most fascinating is that individuals construct intergroup boundaries and discriminate in favor of in-group members in the absence of any factors typically posited to account for intergroup bias.

Creating "us" and "them" in the laboratory: The minimal group paradigm. The ease with which one can generate intergroup bias is best illustrated by the minimal group paradigm (Tajfel, 1970; Tajfel et al., 1971). In these studies, people are told they are assigned to minimal groups on the basis of arbitrary group differences, such as a preference for abstract art or dot estimation abilities (in fact they are randomly assigned). Once they are assigned to groups, participant typically have no face-to-face interaction within or between groups, which prevents any sense of competition or the potential for stereotype activation. Remarkably, randomly assigning participants to minimal groups (even when participants know one another prior to the study) produces discrimination in favor of in-group members. These findings underscore how readily people identify with social groups as well as the context-dependent nature of these identities. 
Creating novel groups is a powerful tool for intergroup neuroscience research because it can be used to isolate the effects of social identification processes: (1) participants do not have any pre-existing stereotypes or associations regarding the in-group and out-group prior to group assignment, (2) theoretically irrelevant group features (e.g., majority/minority status, power, familiarity) can be matched between groups, (3) theoretically relevant group features (e.g. current threat, perceived cohesion) can be effectively and ethically manipulated between groups, (4) there is a natural mechanism for creating neutral targets who are not associated with either group to help differentiate in-group favoritism from out-group derogation (e.g., Van Bavel et al., 2011), and (5) individuals can be randomly assigned and then reassigned to groups, allowing researchers to examine the flexibility of self-categorization processes (e.g., Cikara et al., 2014). Furthermore, novel groups are easy to implement in the lab (e.g., easier than collecting equal numbers of ethnic minority and majority participants). Finally, in our experience, most participants take to their identities quickly and maintain them until another identity becomes salient.

\section{Neural responses to "us" and "them"}

Early results in the neuroscience of intergroup evaluation. The initial neuroimaging research on self and social categorization focused on the amygdala-a small structure in the temporal lobe (see Figure 1). The amygdala has been implicated in a host of social and affective processes, including fear conditioning and processing negative stimuli (for a review see Phelps, 2006). Building on this work, several functional magnetic resonance imaging (fMRI) studies of social categorization found that Black and White perceivers exhibited relatively greater amygdala activity when viewing other-race faces than own-race faces (Hart et al., 2000) and that individual differences in amygdala activity to other-race faces were correlated with implicit 
measures of racial bias - including startle eye-blink and the Implicit Association Test (IAT) (Cunningham et al., 2004; Phelps et al., 2000). These correlations with racial bias, coupled with studies demonstrating a link between the amygdala and fear conditioning (LeDoux, 1996), led some researchers to interpret differences in amygdala activity to other-race faces as evidence of negativity (including disgust and fear) toward stigmatized groups.

Despite the robust relationship between the amygdala and negative stimuli, several studies have shown that the amygdala also responds to highly arousing stimuli more generally (Anderson et al., 2003; Cunningham, Raye, \& Johnson, 2004) including positively arousing stimuli (Hamann, Ely, Grafton, \& Kilts, 1999). As such, the amygdala may play a role in directing attention to any motivationally-relevant stimuli, regardless of valence (Cunningham \& Brosch, 2012; Cunningham, Van Bavel, \& Johnsen, 2008; Vuilleumier \& Brosch, 2009). When race is the most salient social category - as is often the case in experiments where participants are presented with hundreds of black and white faces - the amygdala may indeed be responsive to members of groups that are novel (Dubois et al., 1999) or associated with threatening stereotypes or prejudice (Phelps et al., 2000). However, when race is not the most salient social category, the amygdala may be responsive to members of groups, who are motivationally relevant for other reasons (see Van Bavel \& Cunningham, 2011).

Re-interpreting findings from the neuroscience of intergroup evaluation. In minimal groups, in-group members tend to be motivationally relevant because they afford group members the opportunity to fulfill belonging needs and other core social motives; furthermore, minimal out-group members are not associated with any specific stereotypes (Hugenberg, Young, Bernstein, \& Sacco, 2010; Van Bavel \& Cunningham, 2012; Van Bavel, Swencionis, O'Connor, \& Cunningham, 2012). To test the hypothesis that the amygdala would respond more to a novel 
in-group as compared to out-group members, one study randomly assigned White participants to a minimal mixed-race group, had them briefly learn the members of each group, and then presented them with in-group and out-group faces during functional magnetic resonance imaging (fMRI; Van Bavel, Packer \& Cunningham, 2008). Crossing race and group membership provided a clean investigation of the role of group membership in neural processing because it diminished differences between in-group and out-group members on familiarity, novelty, and other factors. Likewise, the novel groups had no pre-existing stereotypes and the images were counterbalanced to rule out any visual differences between in-group and out-group members. Whereas earlier studies had often interpreted amygdala activity to other races faces as reflecting negativity or fear, perceivers in this experiment had greater amygdala activity to members of their novel in-group. Specifically, people exhibited greater amygdala activity to ingroup than out-group faces. There was no main effect of race, nor was this pattern of in-group bias moderated by target race. Strikingly, this pattern of in-group bias in neural processing occurred within minutes of group assignment, in the absence of explicit team-based rewards or social interaction, and independent of pre-existing racial bias, stereotypes, or familiarity. This suggests that social identification with a group — even a seemingly trivial group — can guide neural responses to social targets. Subsequent studies confirmed that assigning people to mixedrace teams can even override racial biases on relatively automatic measures of evaluation (i.e., evaluative priming task; see Van Bavel \& Cunningham, 2009) and that the effects of novel group membership can influence perceptual processes within the first few hundred milliseconds of perception (Ratner \& Amodio, 2013; Van Bavel, Earls, Morris, \& Cunningham, 2013)

This research underscores the idea that the relevance of different social categories varies according to the immediate social context (Turner et al., 1987). In contexts where race provides 
the most salient group distinction, racial attitudes, cultural stereotypes, and personal values (e.g., egalitarianism) may provide the most relevant frameworks for perception and action. Assigning people to mixed-race groups, on the other hand, may change the way people construe race and other social categories and sensitize perceptual and evaluative processes to other contextually relevant group memberships (Kurzban, Tooby, \& Cosmides, 2001). Subsequent work has examined the influence of these contextually determined social identities on basic face processing and social memory.

Perceiving "us" and "them." For nearly a century, scientists have known that people are better at recognizing faces from their own racial or ethnic groups compared to faces from other racial groups (Feingold, 1914). This phenomenon, typically termed the own-race bias, has largely been explained in terms of experience with own-race faces (i.e., people have a lifetime of experience identifying members of their own race; Malpass \& Kravitz, 1969; Sporer, 2001). For instance, one influential neuroimaging study found that Black and White participants showed heightened activity in the Fusiform Face Area (FFA) to own-race relative to other-race faces (Golby et al., 2001). The FFA - a face sensitive sub-region of the fusiform gyri (see Figure 1) plays an important role in processing and individuating faces (Kanwisher, McDermott, \& Chun, 1997; Rhodes, Byatt, Michie, \& Puce, 2004) and perceptual expertise (Gauthier, Tarr, Anderson, Skudlarski, \& Gore, 1999). Participants with the strongest FFA activity to own-race (relative to other-race) faces also displayed the greatest own-race bias on a subsequent recognition memory task, leading the authors to suggest that own-race biases in fusiform activity may have been due to superior perceptual expertise with own-race faces (Golby et al., 2001; see also Feng et al., 2011). 
Although studies have shown that life-long experience with own-race faces is associated with own-race bias (Sangrigoli, Pallier, Argenti, Ventureyra, \& de Schonen, 2005), interracial contact (a proxy for expertise) only explains $2 \%$ of the own-race bias effect (Meissner \& Brigham, 2001). As a result, researchers have sought alternative theoretical frameworks to explain own-race bias. Sporer (2001) and others have argued that categorizing others as owngroup versus other-group members may alter the depth or type of processing the targets receive, such that own-race faces are processed as individuals (encoded at a subordinate level) and otherrace faces are processed as interchangeable representatives of a social category (encoded at a superordinate level; see also Hugenberg et al., 2010; Levin, 1996, 2000). Indeed, the own-race bias has been replicated across a variety of non-racial social categories, including minimal groups, demonstrating that mere categorization with a group can enhance the recognition of ingroup relative to out-group faces, even when prior exposure to in-group and out-group members is equivalent (Bernstein, Young, \& Hugenberg, 2007; Van Bavel \& Cunningham, 2012). This suggests that social identity may also motivate enhanced encoding of in-group members' faces.

Building on this work, Van Bavel and colleagues $(2008 ; 2011)$ examined whether members of novel groups would encode in-group members at an individuated, subordinate level and out-group members at a categorical, superordinate level. Specifically, they predicted that deeper encoding of in-group members would be reflected in differences in fusiform activity for in-group compared to out-group members, despite similar exposure to members of both groups. Given the role of the fusiform gyrus - especially the FFA - in perceptual expertise, White participants might have been expected to show greater fusiform activity to own-race relative to other-race faces. However, given the role of the fusiform in individuation (see Kanwisher et al, 1997; Tarr \& Gauthier, 2000), the authors expected that participants would show greater 
fusiform activity to in-group relative to out-group faces, regardless of race. Consistent with the latter hypothesis, participants exhibited greater activation within the bi-lateral fusiform gyri for in-group than out-group faces (Van Bavel et al., 2008). Importantly, there was no main effect of race nor was this pattern of in-group bias moderated by race (see also Hehman, Maniab, \& Gaertner, 2010; Van Bavel \& Cunningham, 2012).These results provided evidence that the fusiform may be sensitive to shifts in self-categorization, individuating faces imbued with psychological significance by virtue of their group membership .

Subsequent research has linked this pattern of in-group bias directly to behavior. In a follow-up experiment, the same authors examined the FFA specifically, using a face-localizer task. They not only replicated the pattern of in-group bias reported above, but they also found that FFA activity mediated the effects of group membership on recognition memory - a behavioral index of individuation. Specifically, there was a positive correlation between the individual differences in FFA activity to in-group versus out-group faces and recognition memory differences for in-group versus out-group faces (Van Bavel, Packer, \& Cunningham, 2011). Similarly, several electroencephalography (EEG) papers have found that novel group membership can influence very early components of face processing (i.e., within the first few hundred milliseconds). For instance, a recent paper found that people have greater N170 responses - an event-related potential implicated in facial identity encoding - to minimal ingroup than out-group faces (Ratner \& Amodio, 2013). Other work suggests that in-group members are perceived faster than out-group members (Zheng \& Segalowitz, 2013) and that these group affiliations can override initial racial biases in perceptual processing (Van Bavel et al., 2013). Taken together, these findings imply that once people identify with a group, in-group members are more likely to be processed as individuals in a non-categorical fashion than out- 
group members, consistent with social cognitive models of person perception. However, the time course of these signals suggests that motivational concerns may influence face processing earlier than many social cognitive models suggest.

Consistent with these findings, recent research suggests that social memory is also sensitive to social identity (see Hugenberg et al., 2010 for a review). Importantly, the motivational aspects of the perceiver's social identity shape social attention and memory over and above mere categorization into groups (Van Bavel \& Cunningham, 2012; Van Bavel et al., 2012). For instance, people, who have a high need to belong or who are highly identified with their in-group appear to have the largest memory advantage for in-group versus out-group faces. However, social roles can attenuate in-group bias: for example, memory for out-group faces was heightened among participants who were assigned to be a "spy," a role that required greater attention toward out-group members. This research suggests that many aspects of social identity - from collective identification to specific social roles - are responsible for shaping social perception and memory.

More generally, there is evidence that the influence of social identity extends far beyond face perception. Confirming the experience of countless sports fans, one classic paper found that students from two different universities had very different perceptions of the same football game, recalling different "facts" about the game (e.g., irrespective of team allegiance, fans recalled with great certainty that the other team had played dirty; Hastorf \& Cantril, 1954). A related, recent neuroimaging paper found evidence that groups might indeed bias basic perceptual processing of in-group versus out-group targets' actions (Molenberghs, Halazs, Mattingly, Vanman, \& Cunnington, 2013). The authors randomly assigned participants to the red team or blue team and had them judge the speed of hand movements performed by both in-group and out-group 
members. Participants judged the actions of in-group members as faster than the identical actions of out-group members; this intergroup bias was associated with activity in the left inferior parietal lobule - a region that has previously been implicated in transforming visual representations of actions to the motor system for action (see Rizzolatti \& Fabbri-Destro, 2008; Rizzolatti \& Craighero, 2004). This work converges with several recent behavioral studies suggesting that group allegiances can play a role in structuring basic perceptions of the social and physical world (Caruso, Mead, \& Balcetis, 2009; Xiao \& Van Bavel, 2012; Young, Ratner, \& Fazio, 2013).

Effects of "us" and "them" on higher-order social cognition. It is important to note that differences between processing in-group and out-group targets are not confined to perceptual and evaluative processes. Higher order social cognition also appears to be sensitive to social identity concerns: for example, people are more accurate when inferring the mental states of own-race relative to other-race targets (Adams et al., 2010). Building on the hypothesis that "we" is represented similarly as "I", several neuroimaging studies have attempted to identify an overlap between the brain regions implicated in self-referential processing, such as the medial prefrontal cortex (mPFC adjacent to the pregenual anterior cingulate cortex; Kelley et al., 2002; Mitchell, 2009; see Figure 1), and representation of in-group members. For instance, people assigned to a minimal group showed greater activation in the dorsal mPFC when they had to choose between allocating points to an in-group versus out-group member (as opposed to two in-group or two out-group members); this activation was correlated with in-group bias (i.e., awarding more points to in-group than out-group players; Volz et al., 2009). Other research has found that ingroup relative to out-group labels of both real social groups (e.g., "male”, “Australian”) 
(Morrison et al., 2012) and novel groups (e.g., Red Team vs. Blue team; Molenberghs \& Morrison, 2012) were associated with greater activation in the mPFC.

Although the regions reported in these papers are more dorsal than the region of mPFC that is usually associated with self-referential processing (e.g., Denny, Kober, Wager, \& Ochsner, 2012; Jenkins \& Mitchell, 2011), these findings led the authors to infer that social and personal identity processes draw on overlapping neural substrates (see also Scheepers et al., 2013). It is important to keep in mind that the "self" is not a static representation stored in an isolated region of the brain, but rather an online construction derived from contextually determined patterns of activation across networks involving many different regions of the brain (Smith, Coats, \& Walling, 1999). As such, social identities and specific group memberships also involve dynamic construction of collective self-representation (Aron et al., 1991; Packer \& Van Bavel, 2013; Turner et al., 1987).

\section{Summary}

Taken together, these studies support the notion that social identification involves a highly flexible shift in self-representation from the personal to the collective and that this shift can override the influence of visually salient social categories on perception, evaluation, and other aspects of cognition. One important implication is that many social categories are poor proxies for group membership because they are associated with a host of other variables. This research marks the initial phase of work on novel groups in social neuroscience and future work will likely continue to revise existing theories of the neural bases of social categorization and intergroup relations. It is important to note, however, that work with novel groups should complement, rather than replace, work with existing social groups (e.g., race-based categories). 
Intergroup relations are complex and inviting a synthesis of both perspectives likely offers the greatest hope for understanding and attenuating intergroup conflict.

\section{FORCES THAT UNITE AND DIVIDE “US" AND “THEM"}

An integrative theory of intergroup relations must appreciate not only that group membership is flexible and highly context dependent, but also that not all out-groups are equivalent. People today encounter a far greater number and variety of out-group members than their ancestors; however, the fundamental questions that govern social interactions remain the same. Whenever we encounter a novel person or group we are motivated to answer two questions as quickly as possible: the first is "friend or foe?"; the second is "is this agent capable of enacting their intentions toward me?" Specifically, functional relations between groups-are your goals concordant, discordant, or entirely independent of ours? - and status-do you have access to resources? - largely determine the course of intergroup interactions (Cuddy, Fiske, \& Glick, 2007; Fiske, Cuddy, \& Glick, 2007; Fiske, Cuddy, Xu, \& Glick, 2002). As such, one alternative to studying intergroup relations with existing social groups and categories is to manipulate these structural variables among novel groups. The primary strength of this approach is that it provides experimental control over confounding factors and allows for more precise inferences about the underlying causal nature of different aspects of the intergroup context. Accordingly, insights from this approach should have greater generalizability across intergroup contexts and may allow for greater specification for potential interventions (see Billig, 1976). Here we review the effects of functional relations (i.e., cooperation, competition) and relative group status on the neural bases of intergroup interactions. We then explore some of the effects of these structural variables on intergroup interactions, including effects on empathy, help, and harm between groups. 


\section{The role of functional relations in intergroup dynamics}

Extensive evidence suggests that random assignment to minimal groups can elicit intergroup bias - even in the absence of intergroup hostility. Beyond mere group membership, one key amplifier of intergroup bias is the perception of a zero-sum relationship between the respective groups' goals (Fiske \& Ruscher, 1993; see also Struch \& Schwartz, 1989). Even in the absence of actual competition, the mere perception of groups as competitive engenders negative emotions toward them (Fiske et al., 2002). Making competition explicit increases intergroup hostility in part because it makes social identity more salient (Hogg, 1992, 1993; Mullen, Brown, $\&$ Smith, 1992). For all these reasons, competitive functional relations increase intergroup conflict and out-group derogation (Deutsch, 2006; Johnson \& Johnson, 1989; Sherif 1961).

In addition to the flexibility of social identification with groups (Turner et al., 1994), the functional relations between groups (and the consequences thereof) are also malleable (Sherif, Harvey, White, Hood, Sherif, 1954/1961; Tajfel \& Turner, 1979). Groups that have previously had cordial relations may become competitive. The fluid nature of functional relations between groups, however, is also reason to be optimistic about interventions in intergroup conflicts: if perceptions or the salience of intergroup relations can be changed, individuals may overcome hostility toward previous enemies (Sherif et al., 1961), even when in the context of socially meaningful identities that are linked to deeply held political beliefs, gender, or race. For example, during the fiercely contested 2008 Democratic presidential primary process, Hillary Clinton and Barack Obama supporters gave more money in a dictator game to strangers who supported the same primary candidate (compared to the rival candidate). Two months later, after the Democratic National Convention, the supporters of both candidates coalesced around the party nominee-Barack Obama - and this bias disappeared (Rand et al., 2009). Along with the 
findings that novel teams can override race categorization (e.g., Kurzban et al., 2001; Van Bavel \& Cunningham, 2011), these findings fit well with decades of research on common in-group identity (Gaertner \& Dovidio, 2000; Sherif et al., 1961). The moment-to-moment motivational salience of specific functional relations can modulate attitudes, emotions, and behaviors.

Surprisingly, very little research has explored the biological bases of intergroup competition and cooperation as well as group-based social status inference. In the sections that follow, we review the relevant literature and include some of the recent work on these topics in the context of interpersonal interactions as the basis for generating novel hypotheses about these processes at the group level.

\section{The neuroscience of competition and cooperation}

The last decade has seen an explosion of research examining the neural substrates of cooperation and competition between individuals (see Rilling \& Sanfey, 2011). By some accounts, people cooperate because it is inherently rewarding (Zaki \& Mitchell, 2013). For example, in one study, playing a game with another person in both cooperative and competitive contexts (relative to playing alone) recruited the frontoparietal network, which is associated with executive control (e.g., Vincent et al., 2008); however, when the two social interaction conditions were contrasted against one another, cooperation, relative to competition, elicited a relatively greater response in orbitofrontal cortex (among other regions), which the authors interpreted as reflecting a reward response (Decety, Jackson, Sommerville, Chaminade, \& Meltzoff, 2004). Several other studies support the cooperation-as-reward theory: for example, ventral striatum (also associated with reward registration in the service of optimizing future behavior) responds when individuals observe cooperation (Rilling et al., 2002) and fair resource distribution (Tricomi, Rangel, Camerer, \& O’Doherty, 2010), as well as when individuals choose 
to act equitably (Zaki \& Mitchell, 2011). However, the same neural mechanisms associated with cooperative behavior are also associated with anti-social responses in competitive contexts.

People experience pleasure when they have the ability to punish, or watch the punishment of a disliked or competitive other. When a partner behaved unfairly (i.e., defected) in a game, the dorsal striatum - a region implicated in action selection on the basis of reward value - was relatively more active when people administered punishments that reduced defectors' payoffs, as compared to punishments that did not (De Quervain et al., 2004). Moreover, subjects with stronger activations in the dorsal striatum were willing to incur greater costs in order to punish. Other work has found that seeing the pain of a cooperative confederate activated a network of brain regions associated with first-hand experience of pain; however, seeing the pain of a competitive confederate activated ventral striatum. Further, ventral striatum activation correlated with an expressed desire for revenge (Singer, Seymour, O’Doherty, Stephan, Dolan, \& Frith, 2006). Thus in interpersonal contexts, competition (even among strangers, for low-stakes outcomes) fundamentally changes people's social preferences and corresponding neural responses.

One open question is how moving from an interpersonal to intergroup context affects these processes. Is observing out-group punishment or failure rewarding in competitive intergroup interactions? Perhaps even more so than in interpersonal contexts. There are several reasons to think interpersonal and intergroup processes will manifest differently in degree, and possibly in kind. People trust groups less than individuals and expect interactions with groups to be more hostile than person-to-person interactions (Bornstein \& Ben-Youssef, 1994; Insko \& Schopler, 1998; Pemberton, Insko, \& Schopler, 1996; Wildschut, Pinter, Vevea, Insko, \& Schopler, 2003). In competitive contexts, people cooperate less with out-groups relative to 
individual competitors (Insko, Wildschut, \& Cohen, 2013) and behave more aggressively (e.g., Gotte, Huffman, Meier, \& Sutter, 2012; Hugh-Jones \& Leroch, 2011; Meier \& Hinsz, 2004; Wildschut et al., 2003). Relative to interpersonal contexts, people seem to abandon their preferences for equity and disdain for harming others to an even greater extent when "we" are competitive with “them” (Cohen, Montoya, \& Insko, 2006).

These findings suggest that the biological bases of social preferences may manifest differently in the context of intergroup interactions (particularly competitive interactions) because the expectations and attributions are fundamentally different. For example, as we noted above, several papers have illustrated that participants show increased activity in dorsomedial prefrontal cortex (dmPFC) when thinking the mental states of other individuals (Mitchell, 2009). Activation in this region is higher in response to in-group relative to out-group targets, both existing and novel, in the absence of overt competition (Mitchell et al., 2006; Molenberghs \& Morrison, 2013; Rilling et al., 2008). These results dovetail nicely with the finding that people engage less in spontaneous mentalizing for extreme out-group members (Harris \& Fiske, 2006, 2009). Putting people in competitive intergroup contexts, on the other hand, may show the exact opposite pattern. In competitive or threatening contexts, out-group members, by virtue of the fact that they are more likely to arouse suspicion, may elicit even larger responses in regions associated with mentalizing than in-group members (see Hackel, Looser, Van Bavel, 2013). One possible explanation of this discrepancy is that the minimal group context specifically facilitates in-group preference without any out-group derogation (Brewer 1999; Jetten, Spears, \& Postmes, 2004), whereas an overtly competitive context, in which out-group members' actions are more motivationally relevant (see Ackerman et al., 2006), might increase consideration of out-group members' mental states - especially their agentic capacity. This hypothesized pattern is reflected 
in recent research which reports that people exhibited greater motor resonance, indexed by musuppression in EEG recordings (an index of sensorimotor activity), with racial in-group members (relative to out-group members) when the targets made benign gestures; however, the pattern was reversed when targets made offensive gestures (i.e., "giving someone the finger;" Gutsell \& Inzlicht, 2013). Thus, people exhibited greater motor resonance with out-group members when those targets became threatening. Related, recent evidence suggests that the emotional suffering of a threatening out-group member not only elicits as much activity in mentalizing regions as ingroup suffering does, but also more activity than neutral out-group suffering (Bruneau, Dufour, $\&$ Saxe, 2012). Processes ranging from motor resonance to empathy for emotional suffering can be brought on-line when out-groups pose an active threat.

Recent work in an intergroup context using different relational structures has also revealed new insights about oxytocin - a hormone that acts as a neuromodulator in the brain. Interest in the effects of oxytocin on human behavior has boomed in the last decade, with several researchers and media outlets referring to it as the "love hormone" because of its role in facilitating social affiliation and pro-social behavior (Bartz \& Hollander, 2006). However the effects of oxytocin are inconsistent and highly context-dependent (Bartz, Zaki, Bolger, \& Ochsner, 2011). Rather than promoting universal other-concern and affiliation, once people are divided into groups (both ethnic and arbitrary groups), oxytocin administration yields greater ingroup favoritism relative to a placebo. Specifically, people exhibit greater positive associations with their in-group and contribute more resources to an in-group pool in an intergroup prisoner's dilemma game (De Dreu et al., 2010; De Dreu, Greer, Van Kleef, Shalvi, \& Handgraaf, 2011). However, there is no difference between people who receive oxytocin and controls with regard to negative associations with the out-group or contribution of resources to an "out-group harm" 
pool. Together these findings indicate that oxytocin administration selectively enhances in-group love, but does not engender out-group derogation (Brewer, 1999).

Subsequent research has examined the effects of oxytocin when the out-group represents an active threat. When the payoffs in the prisoner's dilemma game were structured so that the out-group had the potential to hurt the in-group, participants who received oxytocin were more likely to defect on behalf of their in-group. Self-report data revealed that oxytocin recipients engaged in these "preemptive strikes" against the out-group, not because they thought out-group defection was more likely, but because they wanted to minimize harm to the in-group (see also De Dreu, Shalvi, Greer, Van Kleef, \& Handgraaf, 2012). Thus, by some accounts, oxytocin's facilitation of this response is largely parochial, leading to in-group favoritism and ethnocentric behavior (De Dreu, 2012). On the other hand, a recent study reports that administration of oxytocin increased Israeli Jewish participants' empathy for individuated Palestinian targets’ pain (Shamay-Tsoory et al., 2013); this finding supports the hypothesis that oxytocin heightens the salience of social information (Henrichs, von Dawans, \& Domes, 2009), which may increase pro-social responses towards identifiable victims, even if they are members of an out-group (Chen, Kumsta, \& Heinrichs, 2011). These findings clearly indicate that we need to conduct further research to understand the circumstances under which oxytocin exacerbates versus reduces intergroup prejudice and conflict.

More recent research has started to investigate the neuroendocrine substrates, specifically, of overt out-group aggression. Building on findings demonstrating that human and many other non-human vertebrate males exhibit increases in testosterone-a steroid hormone - in anticipation of fighting another male (Gladue et al., 1989; Hirschenhauser \& Oliveira 2006; Salvador, 2005; Wingfield et al., 1990; Wobber et al., 2010), a recent study investigated whether 
testosterone levels after competition were modulated by the participant's relationship with the competitor. In the community of Bwa Mawego, Dominica, men who defeated an out-group team member in a game of dominos exhibited significant increases in testosterone, whereas men who beat their friends did not (Flinn, Ponzi, \& Muehlenbein, 2012). Without studying these hormones in intergroup contexts - specifically competitive and cooperative contexts - researchers would not have revealed the parochial nature of the neuroendocrine processes that underlie fundamental help and harm behavioral tendencies. This is yet another example of how the study of intergroup relations can provide important contributions to our understanding of basic biological processes.

\section{The role of status in intergroup dynamics}

Once the question, "friend or foe?" is answered, people want to know to what extent that group is capable of enacting their intentions. Status refers to one's position in a social hierarchy; those higher in the hierarchy have greater access to resources, which can make them a more or less credible threat (Fiske, 1992; Sidanius \& Pratto, 2001). As such, individual and group survival is contingent on members' abilities to infer others' social status and protect or better their own status. These inferences help to "optimize" group behavior (e.g., groups are better able to avoid engaging dominant groups in contests they are sure to lose).

Given the centrality of status to intergroup dynamics, it is not surprising that sensitivity to dominant and submissive cues are present in infancy (Thomsen, Frankenhuis, Ingold-Smith, \& Carey, 2011), and that by the time humans are adults, status inference are reflexive and ubiquitous - even between groups (see Sidanius \& Pratto, 1999; Jost \& Banaji 1994). Status inference is supported, in part, by social comparison (comparing oneself against others in order to determine one's standing), which occurs across human societies (Festinger, 1954; Fiske, 2011; Olson, Herman, \& Zanna, 1986; Suls \& Wheeler, 2000). Social comparisons about status happen 
The neuroscience of intergroup relations 28

quickly, consume few cognitive resources, and can occur outside of subjects' control (Gilbert, Giesler, \& Morris, 1995; Pelham \& Wachsmuth, 1995; Wedell, 1994). Indeed, evidence from EEG studies suggests that inferences of social status from facial cues occur within $170 \mathrm{~ms}$ (Chiao et al., 2008). Whether or not we intend it, we register others' social status immediately. The trouble with automatic status comparisons is that they often highlight one's own (or one's group's) relatively lower-status, which can have negative cognitive and affective consequences (e.g., Brickman \& Bulman, 1977; Tesser, Millar, \& Moore, 1988) and induce stress, which has negative health implications over the long-term (Segerstrom \& Miller, 2004). Conditions are not entirely rosy for groups with high-status either. Competitive, high-status social groups elicit emotions like envy, which attracts punishment and aggression, both overt and subtle (Cuddy et al., 2007). For example, women who occupy high-power positions in the workplace are frequently targets of backlash (e.g., hiring discrimination, harsher appraisals, and sabotage; Rudman \& Fairchild, 2004). In general, targets that are seen as high-status are also perceived as being capable of defending themselves, so it seems more acceptable to harm them (Cikara, Farnsworth, Harris, \& Fiske, 2010; Glick, 2002).

\section{The neuroscience of social status inference}

Understanding the biological bases of social status inference is important for several reasons, not least of which is because status is a fundamental feature of our social lives that has implications for our happiness and well-being, and also intergroup conflict (Fiske, 2012).

Neuroimaging studies document a reliable network of brain regions associated with social status inference, including the inferior parietal lobe (IPL; for review, see Chiao, 2010). The IPL is associated with the representation of scalar magnitudes, thus its role in social status inference makes sense: people track rank like they track higher versus lower numerical values (Chiao et al., 
2009). As we have already reviewed, however, social status inference is not a cold, cognitive process; people have associated affective and motivational responses because social status is imbued with value. Accordingly, viewing higher-ranked compared to lower-ranked individuals (relative to oneself) is associated with greater responses in the ventral striatum, which, again, is associated with the salience and registration of rewarding stimuli (Zink et al., 2008). One of the nicest features of these studies is that the researchers manipulated status rather than just measuring it. It is worth noting, however, that follow-up studies revealed that these effects are moderated by participants' own socio-economic status (SES). Individuals with lower SES actually showed a greater ventral striatum response to lower-status targets, whereas individuals with higher SES replicated the original finding (Ly, Haynes, Barter, Weinberger, Zink, 2011). This is not surprising in light of the fact that low and high status groups have divergent goals. Low status groups are motivated to improve their standing, whereas high status groups are driven to defend their position in the hierarchy; as such, groups of differing status respond differently, especially to threat (Derks, Scheepers, Van Laar, \& Ellemers, 2011; Ellemers, Spears, \& Doosje, 2002).

The stability of the hierarchy also plays an important role. When relations are stable, lowstatus group membership (even among arbitrary groups) is associated with cardiovascular indices of threat (i.e., higher blood pressure, lower cardiac output, higher total peripheral resistance); however, when hierarchies are seen as unstable, low-status is associated with a challenge response, and the high-status group members exhibit threat responses instead (Scheepers \& Ellemers, 2005; Scheepers, 2009). Experimental manipulations of stability have revealed that people who operate in an unstable hierarchy exhibit greater activation in the amygdala and $\mathrm{mPFC}$ in response to pictures of higher-status individuals, which the authors interpret as 
The neuroscience of intergroup relations 30

increased status-related reactivity (Zink et al., 2008). Though most hierarchies that affect our day-to-day lives are quite stable (i.e., SES), these studies suggest that changing perceptions about the stability of a given hierarchy may mitigate the stress response that plagues low-status groups.

\section{Implications for empathy, helping, and harm}

Understanding how people represent and process intergroup functional relations and group status are paramount for understanding downstream phenomena such as empathy, help, and harm. Empathy has received a great deal of attention from social and developmental psychologists, and cognitive neuroscience as of late (Cikara, Bruneau, \& Saxe, 2011). "Empathy" as a construct has been used to refer to several distinct, but interrelated processes (Batson, 2009 in Decety \& Ickes, 2009): knowing/feeling what another person is feeling; experiencing compassion in response to another person's distress; feeling motivated to help or improve another's welfare, and so on. Because it promotes pro-social behavior, empathy is an integral element of human experience. Despite its centrality to social life and early emergence in development (Preston \& DeWaal, 2002), empathy is not a universal response. Instead, apathy and antipathy, rather than empathy, are common responses when the target belongs to an outgroup.

Most of the extant research explores intergroup empathy bias in the context of existing social and cultural groups (e.g., Cuddy et al., 2007; Decety, Echols, \& Correll, 2009; Johnson et al., 2002). Behavioral and neuroscience studies both find that people show decreased, and sometimes absent empathic responses when witnessing a racial out-group relative to an in-group member in physical and emotional pain. Even motor-simulation responses, which are theorized to support empathic responding via perception-action coupling, vary by target group membership (Gutsell \& Inzlicht, 2010). For example, Black and White participants show sensorimotor 
resonance when an in-group member's hand (even an artificially colored, purple hand) is pricked by a pin; however, this response is not just reduced, it is absent when the hand belongs to an outgroup member (Avenanti, Sirigu, \& Aglioti, 2010). A convergent study reports that white participants exhibit comparable skin conductance responses - an index of automatic arousal - to images of White and Asian targets' painful experiences, but significantly lower responses to Black targets' painful experiences (Forgiarini, Galluci, \& Maravita, 2011). Finally, a recent EEG study reports that participants' patterns of neural responses when they feel sad are similar to those exhibited when they see an in-group, but not an out-group member, expressing sadness (Gutsell \& Inzlicht, 2012). Across these studies, people reliably exhibit decreased (if not absent) physiological traces of empathy, broadly defined.

Interestingly, the fMRI research on intergroup empathy reveals a pattern of discrepant effects. Most of these studies have examined the influence of group membership on responses in the so-called 'pain matrix' or shared neural circuit for pain (Decety, 2011; Eres \& Molenberghs, 2013), which includes the anterior cingulate cortex (ACC), supplementary motor area, and the insula (see Figure 1). In line with the studies described above, two fMRI studies report that the 'pain matrix' was more responsive when participants viewed same-race faces (Xu, Zuo, Wang, \& Han, 2009) and hands (Azevedo et al., 2012) relative to other race faces and hands being pricked with a needle. In another fMRI study, however, White participants' responses in the 'pain matrix' were equivalent for White and Black targets' emotional suffering, whereas black participants showed an even greater response to Black relative to White targets' suffering - a response that the authors termed "extraordinary empathy" (Mathur et al., 2010). In a third fMRI study, Israelis and Arabs reported feeling similar amounts of compassion for South American protagonists and protagonists from the in-group, but less compassion for members of the 
threatening out-group (e.g., Israelis reported less compassion for Arab targets). However, responses in the 'pain matrix' were equivalent for in-group and threatening-out-group members, and decreased for South American targets (Bruneau, Dufour, \& Saxe, 2012). Again, the lack of consistent effects across studies likely reflects the fact that race, ethnicity, and nationality covary with multiple dimensions of intergroup context, including perceived competitiveness, social status, and majority/minority status - all of which could affect the intergroup empathy bias. Isolating and testing the effects of these dimensions independently will help reconcile these seemingly discrepant findings.

A few studies have examined real-social groups that are defined almost uniquely by a competitive context - sports fans. Sports fans are interesting to study because sports is one of few domains in which it is acceptable to express overt antipathy toward out-group members. Unsurprisingly, sports fans are characterized by robust intergroup empathy bias, including both dampened empathy and overt counter-empathic responses (i.e., Schadenfreude; pleasure in response to rivals' misfortunes). In one study, Boston Red Sox and New York Yankees fansarchrival baseball teams - reported pleasure and exhibited activity in ventral striatum when watching rivals fail to score (even against a lower ranked team, the Baltimore Orioles; Cikara et al., 2011). These findings extend to individuals merely associated with the rival team: soccer fans exhibited activity in ventral striatum when watching a rival team's fan receive a painful electric shock (Hein et al., 2010). Greater ventral striatum response to a rival's suffering was associated with an increased desire to harm rival team fans (Cikara et al., 2011) and a decreased willingness to relieve a rival fan's pain (by accepting a proportion of the pain for oneself, Hein et al., 2010). These behavioral responses illustrate the implications of group membership for proand anti-social behavior. 
Only one series of studies to date has focused on assessing the effects of competitiveness and status of stereotyped social groups on empathy and harm. Although these studies also employed existing social groups (e.g., homeless people, investment bankers, elderly targets), the analyses collapsed across the specific groups and analyzed the data using competitiveness and status as the predictors. In one study, participants read about positive and negative events befalling members of groups that were independently identified as high/low competitive and high/low status (yielding 4 types of targets). In the first study, participants reported that they felt least bad about negative events, and least good about positive events when they befell competitive, high-status group members as compared to other targets: participants did not, however, explicitly report feeling better (i.e., Schadenfreude) when negative events befell competitive, high-status group members as compared to other targets. Facial electromyography simultaneously recorded facial muscle responses, focusing on the zygomaticus major (the cheek muscle), because it correlates with positive affect (Brown \& Schwartz, 1980) and indicates the presence of positive, and not just the absence of negative, affect. Participants exhibited the greatest zygomaticus responses (i.e., smiles) when negative events befell competitive, high-status group members relative to other targets (Cikara \& Fiske, 2012). A follow-up fMRI study replicated the self-report data and further found that participants exhibited greater anterior insula activation in response to competitive, high-status group members' good fortunes. One interpretation is that this insula activation represents a counter-empathic reaction (i.e., envy or resentment). In line with the findings from the Red Sox/Yankees fans study, this "counterempathic" response was correlated with a willingness to harm competitive, high-status targets (Cikara \& Fiske, 2011).

\section{Summary}


Once people have determined that someone is an out-group member, they need to determine what kind? Rather than examine how one or two different combinations of social groups represent and interact with one another, we suggest focusing on social structural variables - functional relations and status. The strength of this approach is that it isn't restricted to specific targets; examining the effects of competitiveness and status allows for predictions about emotional and behavioral responses to any social group about which people harbor stereotypes. In addition to measuring these factors among existing social groups, future studies should manipulate functional relations and relative social status among novel groups in order to control for confounding factors. We believe that down the line this approach will allow for greater specification of potential targets for intervention.

\section{FUTURE DIRECTIONS}

A central assumption of our approach is that organizing future research around classic theories (e.g., Social Identity, Self-Categorization Theory, Realistic Conflict Theory) and contemporary models of intergroup relations (e.g., Stereotype Content Model) with recent research on the neural systems underlying social cognition will move the field toward a more comprehensive theory of the neuroscience of intergroup processes. Although initial, exploratory research was necessary to establish empirical foundations for the field, the mere demonstration that some process or outcome changes depending on whether the target of that process is an ingroup or out-group member is only partially informative because most groups vary on many different dimensions. Therefore we recommend exercising caution against using existing social groups to make more general inferences about group processes.

As we have already outlined, one way to investigate intergroup processes so that the results are more generalizable is to employ novel groups and manipulate the features of interest 
(e.g., functional relations; relative status). Another approach is to examine many different ingroup versus out-group identities (e.g., race, nationality, religion) within a single experiment (Cikara \& Fiske, 2011; Cikara \& Fiske, 2012; Lewis \& Bates, 2010; Morrison, Decety, \& Molenberghs, 2012). If the process or outcome in question is fundamentally about "us" and "them" rather than any specific identity, the results should average out across groups. However the groups are instantiated, we believe this approach offers an important complement to the extant intergroup neuroscience literature on existing social groups and categories (e.g., Kubota et al., 2012). In particular, this approach will allow investigators to test how specific aspects of a person's social identity and intergroup context shape the responses of his or her nervous system. In turn, they can study how neural, neuroendocrine, metabolic and immune systems dynamically influence specific social percepts, motivations, and behaviors (Cacioppo, Berntson, \& Decety, 2010). Here, we highlight several other areas of inquiry that we believe are ripe for investigation.

\section{Future directions in neuroscience}

Structural and functional connectivity. The research covered in this review documents the widely distributed network of brain regions involved in maintaining and updating our representations of "us" and "them." To date, however, most of the research on intergroup neuroscience has focused on the effect of intergroup contexts on circumscribed brain regions (and individual hormones), in isolation from the systems in which they are embedded. This approach neglects the fact that each discrete region supports many psychological processes, and each psychological process engages a complex network of interconnected brain regions, the components of which have both excitatory and inhibitory effects on one another (see Phillips et al., 1984). It remains an open question whether the documented findings are better characterized as reflecting functionally discrete processes (e.g., face perception in the FFA) or integrated and 
distributed processes mediated by anatomical connections (e.g., the extended face processing network; see Friston \& Buchel, 2003, for discussion; Pyles, Verstynen, Schneider, \& Tarr, 2013). As such, it is inappropriate to infer psychological processes from activation of isolated brain regions (Poldrack, 2006). This type of "reverse inference" does a disservice to the field because it engenders inappropriate speculation about the psychological mechanisms underlying intergroup cognitions, affect, and behavior (particularly when activation is considered in the absence of any convergent self-report or behavioral indices of said processes).

We believe that an important future direction in the nascent field of intergroup neuroscience will be the examination of structural and functional connections between different brain regions. Examining connectivity is not only fundamental for understanding the psychological processes supported by specific patterns of activation, but also for shedding light on the interactions between processes that are central to many psychological models. For instance, social psychologists have exerted considerable effort trying to understand the relationship between automatic and controlled processing in the expression of racial bias (Devine, 1989; Fazio et al., 1995; Greenwald et al., 1998). Initial work in social neuroscience suggested that regions associated with cognitive control - including the lateral PFC-might play a role in inhibiting racial bias in regions such as the amygdala, promoting more egalitarian judgments and behavior (e.g., Amodio et al., 2003; Cunningham et al., 2004; Richeson et al., 2003). Recent research has used functional connectivity to provide a more direct assessment of the relationship between the amygdala and the latereal PFC during the perception of Black and White faces (Forbes et al., 2012). As expected, activity in the amygdala was negatively correlated with activity in the orbitofrontal cortex (OFC) and lateral PFC, suggesting that regions associated with control have been recruited to suppress responses associated with racial bias. However, this 
pattern was reversed when participants were exposed to violent rap music, suggesting that controlled processes may also be recruited to increase gain in-or even up-regulate (Ochsner et al., 2004) - racial bias in certain contexts (see Crandall \& Eshleman, 2003). This research highlights the potential value for using functional connectivity to test and develop process models of intergroup relations.

The effects of individual differences in anatomy on intergroup bias have also garnered increasing interest as of late. For example, individual differences in biological structure (i.e., decreased grey matter volume in dorsal $\mathrm{mPFC}$ ) are associated with increased intergroup bias (Baumgartner, Schiller, Hill, \& Knoch, 2013). Future research could examine how individual differences in white matter microstructural integrity - particularly of pathways within hypothetically relevant networks - relate to representation of in-group and out-group boundaries and relations. The growing popularity of neuroimaging techniques that visualize the anatomical connections between different parts of the brain (e.g., diffusion tensor imaging) will likely promote a greater appreciation of the role of structural networks in intergroup relations.

Networks of brain regions. Shifting the focus from isolated brain regions to collections of functionally and/or anatomically connected brain regions should also generate greater interest in well-established networks that are likely engaged in intergroup cognition and behavior. The reverse-inference problem we discussed above applies to networks in the same way it does to individual brain regions; however, framing research questions in terms of how networks associated with a given psychological process respond in intergroup contexts can generate more specific hypotheses and better constrain post-hoc theorizing about whole-brain activations. To date, few investigations have taken this approach (Mathur and colleagues, 2012, represent one notable exception). 
The neuroscience of intergroup relations 38

Although research on networks has been somewhat neglected in intergroup neuroscience, many of the core psychological processes we have discussed-representing "us," "them," related affective and semantic associations, generating emotional and behavioral responses to in-group and out-group targets - are associated with well-articulated networks. First, there are networks that have, by some accounts, evolved or been co-opted specifically to support social interaction. For example, the default mode network (DMN) is a system of regions that is activated when individuals engage in conscious or unconscious introspection and mind-wandering (Buckner et al., 2008; Christoff et al., 2009; Mason et al., 2007; Raichle et al., 2001). Interestingly, the mentalizing network, which includes regions associated with action perception and inferring others' beliefs and traits, largely overlaps with the DMN (e.g., Aichhorn et al., 2009; Frith \& Frith, 2000; Saxe and Kanwisher, 2003). This has led some researchers to speculate that our "default" is to think about other people (e.g., Mitchell, 2008; Shilbach et al., 2008). What is fascinating about this network is that it is only recruited when people engage truly social cognition (e.g., impression formation as opposed to memorizing a list of facts about a person; Mitchell et al., 2006). In complement, evidence suggests that a specific region of this network is less active when people view images of extreme out-group targets, who people typically avoid (Harris \& Fiske, 2006). These networks likely mediate a considerable amount of intergroup cognition and behavior and are therefore prime targets for investigation.

Likewise, several domain-general networks, which are not dedicated specifically to social processes, are likely implicated in the detection and identification of in-group and out-group members, as well as the generation of approach and avoidance motivations and behaviors. For instance, dissociable networks have been implicated in the detection of salient or novel stimuli (Hughes, 2007; Kiehl et al., 2001; Ranganath \& Rainer, 2003; Squire, Stark, \& Clark, 2004), 
reward processing and appetitive behavior (Delgado, 2007; Grabenhorst \& Rolls, 2011; Kable \& Glimcher, 2009; Knutson \& Cooper, 2005; Levy \& Glimcher, 2012; Montague \& Berns, 2002; O'Doherty, 2004; Peters \& Büchel, 2010), avoidance and aversive responses (Barrett \& Wager, 2006; Yamada \& Decety, 2009), and executive function and cognitive control (Amodio, 2008; Forbes \& Grafman, 2010; Richeson et al., 2003). The last two decades of intergroup neuroscience research have seen an explosion of foundational, but somewhat exploratory brainmapping. Our belief is that future research, which places an emphasis on hypothesis testing in networks, will make significant strides toward building predictive, multilevel models of a variety of intergroup phenomena.

Genetic approaches. Though both "nature" and "nurture" contribute to neural anatomy, individual differences in anatomical structure (and their relationship to prejudice) have increased interest in the heritability of intergroup biases. A recent study with an adult, German twin sample reports that monozygotic twins were more highly correlated than dizygotic twins on nationalism, patriotism, and generalized prejudice scores; however, further modeling accounting for (non)shared environmental effects found evidence only for the heritability of in-group love, not out-group derogation (Lewis, Kandler, \& Rieman, 2013). Findings like these have sparked the search for the genetic bases of bias. For example, one study examined the interaction between OFC lesions and single nucleotide polymorphisms on implicit gender bias. These findings suggest that increased neural plasticity in OFC, facilitated by certain polymorphisms, may contribute to the inhibition of stereotype activation (Forbes et al., 2011). In another study, which examined the interaction between genetics and the environment on intergroup bias, participants with at least one short-allele of serotonin transporter gene polymorphism (5-HTTLPR), were more prejudiced and exhibited more discriminatory behavior toward a threatening out-group 
relative to a non-threatening out-group; participants with two long-alleles, on the other hand, did not respond to the two out-groups differently (Cheon, Livingston, Hong, \& Chiao, 2013). These recent studies build on a rich literature based on animal-models of social behavior (e.g., Robinson, Fernald, \& Clayton, 2008), and represent the beginning of a new branch of human social neuroscience, integrating molecular, cellular, and systems levels of analysis. This work has the potential to elucidate more precise biological mechanisms that give rise to biased attitudes and behaviors toward out-groups.

Enthusiasm for this approach, however, must be tempered by the understanding that there is not a one-to-one mapping between single candidate genes and particular behaviors. Individual genes do not, in isolation, determine behavior; they interact with other genes, and these complex interactions further interact with an individual's environment (including other people, who have their own genetic constitutions). As such, a correlation between a particular polymorphism and, for example, prejudicial or discriminatory tendencies, should not be taken as evidence of the hard-wiring of a given psychological or behavioral phenomenon (Ratner \& Kubota, 2012).

Other tools and approaches. Though EEG and fMRI are currently the most popular methods for investigating the neural bases of intergroup relations, many other complementary methods may help refine and revise existing theories. For instance, magnetoencephalograhy (MEG) is a technique for mapping brain activity that offers the best of both worlds: the temporal resolution of EEG and the spatial resolution of fMRI. MEG affords the possibility of examining the activity of neural systems as it unfolds in real time. This is particularly exciting in the context of networks of brain regions, as one could examine how the temporal dynamics of hypothesized networks (e.g., salience $\rightarrow$ evaluation) vary as a function of the target and the task at hand. This tool also captures a recent paradigm shift in systems neuroscience as conceptualizations of 
human cognition have shifted from emphasizing the role of discrete regions to the dynamic interactions among multiple regions unfolding over time (e.g., Cunningham et al., 2007; Honey et al., 2012; Lerner et al., 2011).

Work with lesion patients has also had a huge impact on the neuroscience of judgment and (non)social decision-making (e.g., Bechara, Tranel, \& Damasio, 2000; Koenigs et al., 2007; Young et al., 2010a). Two studies have already used this approach to examine the role of the amygdala and OFC in race (Phelps, Cannistraci, \& Cunningham, 2003) and gender (Milne \& Grafmann, 2001) bias, respectively. In addition to brain lesions, more work could be done using techniques like temporary transcranial magnetic stimulation and transcranial direct current stimulation to examine the causal role of different brain regions in target psychological processes (e.g. Young et al., 2010b), and to provide greater specificity about the necessity and sufficiency of implicated regions.

Several other recent and exciting findings highlight additional avenues for future research. Work in psychopharmacology highlights the possibility of administering drugs as intergroup conflict interventions: for example, exogenously administered propranolol has been shown to reduce implicit racial bias (Terbeck et al., 2012). Studies in comparative psychology and neuroscience have revealed that neural circuits, which support the function of nonsocial behaviors critical for survival (e.g., escape), similarly support social cognition, decision-making, and behavior (e.g., gaze aversion; Chang et al., 2013). Finally, we believe that there is a lack of work at the computational level-of-analysis, which is ultimately necessary to bridge the neural and psychological levels-of-analysis in intergroup neuroscience (Freeman \& Ambady, 2011). Ultimately, a complete understanding of the neuroscience of intergroup relations will require the efforts of scientists using all of these methods. 
The neuroscience of intergroup relations 42

\section{Future directions in psychology}

From categories to groups. One relatively unexplored avenue for future intergroup neuroscience research is the difference between the representation of social categories versus social groups. Social categories are inclusive structures that merely require all members share some feature (e.g., brunettes), whereas more "purposive groups...[are] intact social system[s], complete with boundaries, interdependence for some shared purpose, and differentiated member roles" (e.g., a sports team; p. 1210, Hackman \& Katz, 2010). Note that this difference is better characterized as a continuum than a dichotomy; many important social identities lie somewhere in between the two extremes (e.g., Red Sox fans, a category whose members have a shared purpose but do not constitute a purposive group). And, as we have stressed throughout this paper, the salience of different social identities, be they categories or groups, depends largely on the social context.

Many studies have explored the differences between processing a target as a group member (e.g., stereotype activation; Mitchell, Ames, Jenkins, \& Banaji, 2009) as opposed to an individual (e.g., trait attribution; Mende-Siedlecki, Cai \& Todorov, 2012; see Andersen, Klatzky \& Murray, 1990 for direct comparison of the processes), however, few have looked at the features that make some categories and groups more cohesive than others. Extensive research has documented that not all social categories possess the features that give groups their potency: joint actions, shared goals, perceptual or psychological cohesion, group members' similarity to one another, etc. (e.g., Campbell, 1958; Hamilton \& Sherman, 1996; Yzerbyt, Castano, Leyens, \& Paladino, 2000). These features matter because they shape how people respond to members of these groups, including increasing stereotyping, intergroup bias, and hostility (Abelson, Dasgupta, Park, \& Banaji, 1998; Gaertner \& Schopler, 1998; Lickel, Miller, Stenstrom, Denson, 
\& Schmader, 2006; Waytz \& Young, 2012). One priority for future research lies in untangling how our minds and brains extract this information in intergroup contexts. Specifically, intergroup neuroscience research may want to (1) consider the biological substrates of Gestalt laws of perceptual organization as a target system for future research (not unlike the work on social status and IPL which is associated with representing numerical magnitude; Chiao et al., 2008) and (2) examine how this system interacts with other neural systems to evaluate and guide social interactions in group contexts.

The self in social groups. Another important avenue for future research is the investigation of how acting as a member of a group change representations of one's self (Ellemers, 2012; Packer \& Van Bavel, 2014). There is a large literature on how the self and similar versus dissimilar others (in-group and out-group members) are represented in the mind and brain; as we have already noted, representations of similar others and in-group members show greater overlap with self-representations than representations of out-group members do (e.g., Jenkins et al., 2008; Mitchell et al., 2006; Volz et al., 2009). But people's behavior changes when they join groups. For example, individuals tend to engage in more hostile behaviors toward opponents when acting as part of a group than when acting alone (e.g., Meier \& Hinsz, 2004). How and to what extent do self-representations change in intergroup contexts?

A recent fMRI study suggests that acting with a group in a competitive context reduces the salience of one's own personal moral standards. Consistent with previous competitive groups research, participants harmed out-group members more than in-group members. Critically, the degree to which participants were willing to carry out such harm was associated with the degree to which they exhibited reduced activity in a region of mPFC implicated in self-referential processing in response to moral statements. This pattern was only observed when participants 
were competing in a group, not when competing alone. These results suggest that acting as part of a competitive group may reduce the salience of one's own moral standards and, in turn, enable out-group harm (Cikara, Jenkins, Dufour, \& Saxe, 2013). Future research should examine what other aspects of self-representations change when individuals act as representatives of their groups rather than as agents on their own behalf.

A second-person intergroup neuroscience. The third psychological future direction we highlight is a greater incorporation of enriched social stimuli and intergroup interaction in realtime. Most of the literature in intergroup neuroscience can be fairly criticized for focusing on individuals' responses to static images, words, or games representing in-group/out-group members and their behavior. However, social cognition is fundamentally different when people actually interact with others rather than merely observing them or being led to believe they are interacting with them (Schilbach et al., 2013). Real world intergroup interactions are far richer than our current methods appreciate, and likely engage a far broader network of biological substrates. Recent forays into "brain to brain" methods and analyses demonstrate that researchers do not necessarily relinquish experimental control or analytical precision by studying real social interactions (Hasson et al., 2012). For example, in one fMRI experiment, participants played a cooperative game with a partner, knowing that in one condition the partner's behavior was prerecorded, and in the other that they were interacting in real-time via a video feed. Relative to the pre-recorded condition, playing the game in real time elicited greater responses in brain regions associated with social cognition and reward (Redcay et al., 2010). These results suggest that incorporating actual interaction in the neuroscience of intergroup relations may reveal new targets for investigation, including systems that support communication and shared understanding (or a lack thereof, between groups in conflict; Cikara, Honey, Paluck, \& Hasson, 
2013). Future work should therefore move toward dyadic interactions, and ultimately large group interactions, to understand how social identities create emergent "group-level" cognitive phenomenon. This work not only captures the essence of group contexts, but it may also have important implications for understanding and cultivating successful leaders and educators who are tasked with coordinating collective cognition.

Societal and cultural factors. An examination of the influence of societal and cultural backgrounds will continue to play a large role in understanding the boundary conditions of many findings in the neuroscience of intergroup relations (e.g., Chiao, Mathur, Harada, \& Lipke, 2009; Jost \& Amodio, 2012; Moran et al., 2011). For example, Korean and white American participants both exhibited increased $\mathrm{mPFC}$ and bilateral TPJ activation when viewing same-race versus other-race targets' emotional suffering; however, Korean participants reported a significantly larger empathy gap relative to white American participants. This difference was correlated with a cultural preference for hierarchy among Korean participants (Cheon et al., 2011). All intergroup interaction occurs within a broader societal or cultural context and work that examines group processes within these broader contexts - including social dominance hierarchies and system level factors (Sidanius \& Pratto, 1999; Jost \& Banaji, 1994) - is necessary for providing a complete account of intergroup neuroscience. We believe that studying the fundamental structures and features of intergroup relations, using all of these approaches, will continue to advance our understanding of how and why groups and their members behave as they do.

\section{GENERAL DISCUSSION}

Throughout this paper we have highlighted recent findings in the neuroscience of intergroup relations, emphasizing cases in which existing psychological and neuroscience 
theories have been revised once the relevant phenomena have been investigated in intergroup contexts or with novel groups (see Table 1 for a review). Work in this area has already refined extant models of intergroup relations and documented the widely distributed network of brain regions that supports intergroup cognition. Importantly, identifying the biological bases of these processes does not suggest that specific in-group and out-group effects are "hard-wired." On the contrary, one of the major contributions of this recent work is the demonstration of how flexibly these biological systems represent the self and others, carving up the social world into "us" and "them" at the toss of a coin. This is an especially important message to communicate to lay consumers of research on the psychology and neuroscience of intergroup relations since it implies considerable promise for reducing prejudice and intergroup conflict.

Work on racial bias is often interpreted as evidence of more general in-group/out-group processes. While the investigation of social categories such as race is important for understanding pervasive social inequities and obstacles, using this work to make broad inferences about group processes can be problematic for several reasons. First, race is confounded with many other factors including visual properties of the stimuli, familiarity, stereotype content, etc. Thus, it is difficult to know whether the effects are driven by group identification, per se. Second, self-categorization is extremely flexible, meaning that existing theories of the neural bases of intergroup relations are likely limited to specific contexts. We argue that using mixed-race and novel groups, in complement with real groups, and manipulating features of interest (e.g., motivational salience of the in-group versus out-group) will prove useful for advancing theories of the cognitive, affective, and neural bases of intergroup relations.

Integrating classic theories and contemporary models of intergroup relations with the investigation of the biological bases of intergroup dynamics will benefit both psychologists and 
neuroscientists. Not only does our proposed approach account for discrepancies in the existing research, it generates a number of hypotheses and directions for future research. This approach also confers greater consilience; theories that operate at multiple levels of analysis are more likely to stand the test of time and present several opportunities for collaboration between psychologists and neuroscientists (Wilson, 1998). Furthermore, the exchange of knowledge is bidirectional: we emphasize both how biological processes support social cognition and behavior, and how social influences modulate biological processes. The work on intergroup neuroscience should not be construed as a brain-mapping exercise; it is about developing models that can be tested using cognitive and behavioral tasks. Specifically, this research has the potential to benefit the psychological study of intergroup relations, especially when predictions from neural models contradict or adjudicate among multiple psychological models (Mather, Cacioppo, \& Kanwisher, 2013). Although it is beyond the scope of the present paper, it is our hope that greater integration across methods and levels of analysis will ultimately lay the foundation for superior interventions and social policy.

\section{Conclusion}

In summary, initial work on intergroup neuroscience highlights the dynamic nature of social identity and the contextual factors that shape intergroup relations. We believe an understanding of these factors will resolve discrepant findings in the literature, provide organizational principles for understanding the core elements of intergroup dynamics, and help generate novel insights for social, developmental, evolutionary, and cognitive psychologists. Ultimately, we hope this work will help generate novel interventions and inform social policy to reduce intergroup conflict. 


\section{References}

Abelson, R. P., Dasgupta, N., Park, J., \& Banaji, M. R. (1998). Perceptions of the collective other. Personality and Social Psychology Review, 2(4), 243-250.

Ackerman, J. M., Shapiro, J. R., Neuberg, S. L., Kenrick, D. T., Becker, D. V., Griskevicius, V., ... \& Schaller, M. (2006). They All Look the Same to Me (Unless They're Angry) From Out-Group Homogeneity to Out-Group Heterogeneity. Psychological Science, 17(10), 836-840.

Adams Jr, R. B., Rule, N. O., Franklin Jr, R. G., Wang, E., Stevenson, M. T., Yoshikawa, S., ... $\&$ Ambady, N. (2010). Cross-cultural reading the mind in the eyes: An fMRI investigation. Journal of Cognitive Neuroscience, 22, 97-108.

Aichhorn, M., Perner, J., Weiss, B., Kronbichler, M., Staffen, W., Ladurner, G. (2009). Temporo parietal junction activity in theory-of-mind tasks: falseness, beliefs, or attention. Journal of Cognitive Neuroscience, 21(6), 1179-1192.

Allport, G. W. (1954). The nature of prejudice. Reading, MA: Addison Wesley.

Amodio, D. M. (2008). The social neuroscience of intergroup relations. European Review of Social Psychology, 19, 1-54.

Amodio, D. M., Harmon-Jones, E., \& Devine, P. G. (2003). Individual differences in the activation and control of affective race bias as assessed by startle eyeblink responses and self-report. Journal of Personality and Social Psychology, 84, 738-753.

Amodio, D. M., Harmon-Jones, E., Devine, P. G., Curtin, J. J., Hartley, S. L., \& Covert, A. E. (2004). Neural Signals for the Detection of Unintentional Race Bias. Psychological Science, 15(2), 88-93.

Andersen, S. M., Klatzky, R. L., \& Murray, J. (1990). Traits and Social Stereotypes: Efficiency Differences in Social Information Processing. Journal of Personality and Social Psychology, 59, 192-201.

Anderson A.K., Christoff K., Stappen I., Panitz D., Ghahremani D.G., Glover G., Gabrieli J.D., Sobel N. (2003). Dissociated neural representations of intensity and valence in human olfaction. Nature Neuroscience, 6(2):196-202.

Anderson, A. K., \& Phelps, E. A. (2001). Lesions of the human amygdala impair enhanced perception of emotionally salient events. Nature, 411, 305-309.

Aron, A., Aron, E. N., Tudor, M., \& Nelson, G. (1991). Close relationships as including other in the self. Journal of Personality and Social Psychology, 60(2), 241-253.

Ashburn-Nardo, L., Voils, C.I., \& Monteith, M.J. (2001). Implicit associations as the seeds of intergroup bias: How easily do they take root? Journal of Personality and Social Psychology, 81(5), 789-799.

Avenanti, A., Sirigu, A., \& Aglioti, S. M. (2010). Racial bias reduces empathic sensorimotor resonance with other-race pain. Current Biology, 20, 1018-1022.

Azevedo, R. T., Macaluso, E., Avenanti, A., Santangelo, V., Cazzato, V., \& Aglioti, S. M. (2012). Their pain is not our pain: brain and autonomic correlates of empathic resonance with the pain of same and different race individuals. Human Brain Mapping.

Bartz, J., \& Hollander, E. (2006). The neuroscience of affiliation: forging links between basic and clinical research on neuropeptides and social behavior.Hormones and Behavior, 50(4), 518-528. 
The neuroscience of intergroup relations 49

Bartz, J. A., Zaki, J., Bolger, N., Hollander, E., Ludwig, N. N., Kolevzon, A., \& Ochsner, K. N. (2010). Oxytocin selectively improves empathic accuracy.Psychological Science, 21(10), 1426-1428.

Bartz, J.A., Zaki, J., Bolger, N., \& Ochsner, K.N. (2011). Social effects of oxytocin in humans: Context and person matter. Trends in Cognitive Sciences, 15(7), 301-309.

Batson, C. D. (2009). These things called empathy: Eight related but distinct phenomena. In J. Decety, \& W. J. Ickes (Eds.), The social neuroscience of empathy (pp. 3-15). Cambridge, MA: MIT Press.

Baumgartner, T., Schiller, B., Hill, C., \& Knoch, D. (2013). Impartiality in Humans is Predicted by Brain Structure of Dorsomedial Prefrontal Cortex. In press at NeuroImage.

Bechara, A., Tranel, D., \& Damasio, H. (2000). Characterization of the decision-making deficit of patients with ventromedial prefrontal cortex lesions.Brain, 123(11), 2189-2202.

Beckes, L. \& Coan, J. A. (in press). The neuroscience of social relationships. Chapter to appear in J.Simpson and L.Campbell (Eds.) The Oxford Handbook of Close Relationships. New York, Oxford University Press.

Beckes, L., Coan, J.A. \& Hasselmo, K. (2013). Familiarity promotes the blurring of self and other in the neural representation of threat. Social Cognitive and Affective Neuroscience, 8, 670-677.

Bernstein, M., Young, S., \& Hugenberg, K. (2007). The Cross-Category Effect: Mere social categorization is sufficient to elicit an own-group bias in face recognition. Psychological Science, 18, 709-712.

Bernstein, M. J., Young, S. G., \& Hugenberg, K. (2007). The Cross-Category Effect: Mere social categorization is sufficient to elicit an own-group bias in face recognition. Psychological Science, 18, 709-712.

Billig, M. (1976). Social psychology and intergroup relations. London: Academic Press.

Bornstein, G. and M. Ben-Yossef (1994). Cooperation in Intergroup and Single-Group Social Dilemmas." Journal of Experimental Social Psychology (30):52-67.

Brewer, M. B. (1988). A dual process model of impression formation. In T. K. Srull \& R. S. Wyer (Eds.), Advances in social cognition (Vol. 1, pp. 1-36). Hillsdale, NJ: Lawrence Erlbaum Associates, Inc.

Brewer, M. B. (1999). The psychology of prejudice: Ingroup love and out-group hate?. Journal of social issues, 55(3), 429-444.

Brewer, M. B., \& Gardner, W. L. (1996). Who is this "we"? Levels of collective identity and self representations. Journal of Personality and Social Psychology, 71(1), 83-93.

Brewer, M. B., \& Pickett, C. L. (1999). Distinctiveness motives as a source of the social self. In T. Tyler, R. Kramer \& O. John (Eds.), The psychology of the social self (pp. 71-87). Mahwah, NJ: Erlbaum.

Brooks, D. (2009, September 12). The young and the neuro. New York Times. Retrieved August 1, 2013, from http://www .nytimes.com/2009/10/13/opinion/13brooks.html?_r=0.

Brown, D. E. (1991). Human universals. New York: McGraw-Hill.

Brickman, P. \& Bulman, R. J. (1977). Pleasure and pain in social comparison.(In J. M. Suls \& R. L. Miller (Eds.), Social comparison processes: Theoretical and empirical perspectives (pp. 149-186). Washington, DC: Hemisphere.

Brown, S. L., \& Schwartz, G. E. (1980). Relationships between facial electromyography and subjective experience during affective imagery.Biological Psychology, 11(1), 49-62. 
Bruneau, E. G., Dufour, N., \& Saxe, R. (2012). Social cognition in members of conflict groups: Behavioral and neural responses in Arabs, Israelis and South Americans to each other's misfortunes. Philosophical Transactions of the Royal Society B, 367, 717-730.

Bruner, J. S. (1957). On perceptual readiness. Psychological Review, 64(2), 123-152.

Buckner, R.L., Andrews-Hanna, J.R., and Schacter, D.L. (2008) The brain's default network: anatomy, function, and relevance to disease. Annals of the New York Academy of Sciences, 1124, 1-38.

Cacioppo, J. T., Berntson, G. G., \& Decety, J. (2010). Social neuroscience and its relationship to social psychology. Social Cognition, 28(6), 675-685.

Cacioppo, J. T., Berntson, G. G., Sheridan, J. F., \& McClintock, M. K. (2000). Multilevel integrative analyses of human behavior: Social neuroscience and the complementing nature of social and biological approaches. Psychological Bulletin, 126, 829-843.

Cacioppo, J. T., \& Cacioppo, S. (2013). Social Neuroscience. Perspectives on Psychological Science, 8(6), 667-669.

Campbell, D. T. (1958). Common fate, similarity, and other indices of the status of aggregates of persons as social entities. Behavioral Science, 3, 14-25.

Caporael, L. R. (1997). The evolution of truly social cognition: The core configurations model. Personality and Social Psychology Review, 1(4), 276-298.

Caruso, E. M., Mead, N. L., \& Balcetis, E. (2009). Political partisanship influences perception of biracial candidates' skin tone. Proceedings of the National Academy of Sciences, 106, 20168 - 20173.

Chang, S. W., Brent, L. J., Adams, G. K., Klein, J. T., Pearson, J. M., Watson, K. K., \& Platt, M. L. (2013). Neuroethology of primate social behavior.Proceedings of the National Academy of Sciences, 110(Supplement 2), 10387-10394.

Chen, F.S., Kumsta, R., \& Heinrichs, M. (2011). Oxytocin and intergroup relations: Goodwill is not a fixed pie. Proceedings of the National Academy of Sciences, 108(13), E45.

Cheon, B. K., Im, D. M., Harada, T., Kim, J. S., Mathur, V. A., Scimeca, J. M., ... \& Chiao, J. Y. (2011). Cultural influences on neural basis of intergroup empathy. NeuroImage, 57(2), 642-650.

Cheon, B. K., Livingston, R. W., Hong, Y. Y., \& Chiao, J. Y. (2013). Genex environment interaction on intergroup bias: the role of 5-HTTLPR and perceived out-group threat. Social cognitive and affective neuroscience, epub ahead of print.

Chiao, J. Y., (2010). Neural basis of social status hierarchy across species. Current Opinion in Neurobiology, 20(6), 803-809.

Chiao, J.Y., Adams, R.B., Jr., Tse, P.U., Lowenthal, W.T., Richeson, J.A., Ambady, N. (2008). Knowing who is boss: fMRI and ERP investigations of social dominance perception. Group Relations and Intergroup Processes (Special Issue in Social Neuroscience), 11(2), 201-214

Chiao, J.Y., Harada, T., Oby, E.R., Li, Z., Parrish, T., Bridge, D.J. (2009). Neural representations of social status hierarchy in human inferior parietal cortex. Neuropsychologia, 47(2), 354-63.

Chiao, J.Y., \& Mathur, V.A. (2010). Intergroup empathy: How does race affect empathic neural responses? Current Biology, 20, R478-R480.

Chiao, J. Y., Mathur, V. A., Harada, T., \& Lipke, T. (2009). Neural basis of preference for human social hierarchy versus egalitarianism. Annals of the New York Academy of Sciences, 1167(1), 174-181. 
Choi, J. K., \& Bowles, S. (2007). The coevolution of parochial altruism and war.science, 318(5850), 636-640.

Christoff, K., Gordon, A.M., Smallwood, J., Smith, R., \& Schooler, J.W. (2009). Experience sampling during fMRI reveals default network and executive system contributions to mind wandering. Proceedings of the National Academy of Sciences, 106, 8719-8724.

Cikara, M., Botvinick, M. M., \& Fiske, S. T. (2011). Us versus them: Social identity shapes neural responses to intergroup competition and harm. Psychological Science, 22, 306-313.

Cikara, M., Bruneau, E. G., \& Saxe, R. (2011). Us and them: Intergroup failures of empathy. Current Directions in Psychological Science, 20, 149-153.

Cikara, M., Farnsworth, R. A., Harris, L. T., \& Fiske, S. T. (2010). On the wrong side of the trolley track: Neural correlates of relative social valuation. Social cognitive and affective neuroscience, 5(4), 404-413.

Cikara, M., \& Fiske, S. T. (2011). Bounded empathy: Neural responses to out-group targets' (mis)fortunes. Journal of Cognitive Neuroscience, 23, 3791-3803.

Cikara, M., \& Fiske, S. T. (2012). Stereotypes and Schadenfreude: Behavioral and physiological markers of pleasure at others' misfortunes. Social Psychological and Personality Science, 3, 63-71.

Cikara, M., Honey, C., Paluck, E. L., \& Hasson, U. (2013). The neural basis of (mis)communication. Unpublished manuscript.

Cikara, M., Jenkins, A., Dufour, N., \& Saxe, R. (2013). There is less 'I' in teams: Reduced selfreferential neural response during intergroup competition predicts competitor harm. Carnegie Mellon University, unpublished manuscript. Cohen, T.R., \& Insko, C.A. (2008). War and peace: possible approaches to reducing intergroup conflict. Perspectives on Psychological Science, 3(2), 87-93.

Cohen, T.R., Montoya, R.M., \& Insko, C.A. (2006). Group morality and intergroup relations: Cross-cultural and experimental evidence. Personality and Social Psychology Bulletin, 32, 1559-1572.

Correll, J., \& Park, B. (2005). A model of the in-group as a social resource.Personality and Social Psychology Review, 9(4), 341-359.

Cosmides, L. (1989). The logic of social exchange: Has natural selection shaped how humans reason? Studies with the Wason selection task. Cognition, 31, 187-276.

Crandall, C.S., \& Eshleman, A. (2003). A Justification-Suppression Model of the expression and experience of prejudice. Psychological Bulletin, 129, 414-446.

Cuddy, A. J. C., Fiske, S. T., \& Glick, P. (2007). The BIAS map: Behaviors from intergroup affect and stereotypes. Journal of Personality and Social Psychology, 92, 631-648.

Cunningham, W. A., \& Brosch, T. (2012). Motivational Salience Amygdala Tuning From Traits, Needs, Values, and Goals. Current Directions in Psychological Science, 21(1), 54-59.

Cunningham, W. A., Johnson, M. K., Raye, C. L., Gatenby, J. C., Gore, J. C., \& Banaji, M. R. (2004). Separable neural components in the processing of black and white faces. Psychological Science, 15(12), 806-813.

Cunningham, W. A., Raye, C. L., \& Johnson, M. K. (2004). Implicit and explicit evaluation: fMRI correlates of valence, emotional intensity, and control in the processing of attitudes. Journal of Cognitive Neuroscience, 16, 1717-1729.

Cunningham, W. A., \& Van Bavel, J. J. (2009). A neural analysis of intergroup perception and evaluation. In G. G. Berntson \& J. T. Cacioppo (Eds.), Handbook of neuroscience for the behavioral sciences (pp. 975-984). Hoboken, NJ: Wiley. 
Cunningham, W.A., Van Bavel, J.J., Arbuckle, N.L., Packer, D.J., \& Waggoner, A.S. (2012). Rapid social perception is flexible: Approach and avoidance motivational states shape P100 responses to other-race faces. Frontiers in Human Neuroscience, 6, 140.

Cunningham, W. A., Van Bavel, J. J., \& Johnsen, I. R. (2008). Affective flexibility: Evaluative processing goals shape amygdala activity. Psychological Science, 19(2), 152-160.

Cunningham, W. A., Zelazo, P. D., Packer, D. J., \& Van Bavel, J. J. (2007). The iterative reprocessing model: A multi-level framework for attitudes and evaluation. Social Cognition, 25, 736-760.

Decety, J. (2011). The neuroevolution of empathy. Annals of the New York Academy of Sciences, 1231(1), 35-45.

Decety, J., Echols, S., \& Correll, J. (2010). The blame game: the effect of responsibility and social stigma on empathy for pain. Journal of Cognitive Neuroscience, 22(5), 985-997.

Decety, J., Jackson, P. L., Sommerville, J. A., Chaminade, T., \& Meltzoff, A. N. (2004). The neural bases of cooperation and competition: an fMRI investigation. Neuroimage, 23(2), 744-751.

De Dreu, C. K. (2012). Oxytocin modulates cooperation within and competition between groups: an integrative review and research agenda. Hormones and behavior, 61(3), 419-428.

De Dreu, C.K.W., Greer, L.L., Handgraaf, M.J.J., Shalvi, S., Van Kleef, G.A., Baas, M., Ten Velden, F.S., Van Dijk, E., Feith, S.W.W. (2010). The neuropeptide oxytocin regulates parochial altruism in intergroup conflict among humans. Science 328, 1408-1411.

De Dreu, C.K.W., Greer, L.L., Van Kleef, G.A., Shalvi, S., Handgraaf, M.J.J., (2011). Oxytocin promotes human ethnocentrism. Proc Natl A Sci USA 108, 1262-1266.

De Dreu, C. K., Shalvi, S., Greer, L. L., Van Kleef, G. A., \& Handgraaf, M. J. (2012). Oxytocin motivates non-cooperation in intergroup conflict to protect vulnerable in-group members. PloS one, 7(11), e46751.

Delgado, M.R. (2007). Reward-related responses in the human striatum. Annals of the New York Academy of Sciences, 1104, 70-88.

Denny, B. T., Kober, H., Wager, T. D., \& Ochsner, K. N. (2012). A meta-analysis of functional neuroimaging studies of self-and other judgments reveals a spatial gradient for mentalizing in medial prefrontal cortex. Journal of Cognitive Neuroscience, 24(8), 17421752.

Derks, B., Scheepers, D., \& Ellemers, N. (Eds.). (2013). The Neuroscience of Prejudice. Psychology Press.

Derks, B., Scheepers, D., Van Laar, C., \& Ellemers, N. (2011). The threat vs. challenge of car parking for women: How self-and group affirmation affect cardiovascular responses. Journal of Experimental Social Psychology, 47(1), 178-183.

Deutsch, M. (1949). An experimental study of the effects of co-operation and competition upon group process. Human relations.

Deutsch, M. (2006). Cooperation and competition. In M. Deutsch, P. T. Coleman, \& E. C. Marcus (Eds.), The Handbook of Conflict Resolution: Theory and practice (23-42). San Francisco: Jossey-Bass.

De Quervain, D. J. F., Fischbacher, U., Treyer, V., Schellhammer, M., Schnyder, U., Buck, A., $\&$ Fehr, E. (2004). The neural basis of altruistic punishment. Science.

Devine, P. G. (1989). Stereotypes and prejudice: Their automatic and controlled components. Journal of Personality and Social Psychology, 56(1), 5-18. 
Dubois, S., Roission, B., Schiltz, C., Bodart, J. M., Michel, C., Bruyer, R. (1999). Effect of familiarity on the processing of human faces. NeuroImage, 9, 278-289.

Dunbar, R. I. (1998). The social brain hypothesis. Evolutionary Anthropology, 9, 178-190.

Dunham, Y. (2011). An angry= Outgroup effect. Journal of Experimental Social Psychology, 47(3), 668-671.

Dunning, D., \& Hayes, A. F. (1996). Evidence of egocentric comparison in social judgment. Journal of Personality and Social Psychology, 71, 213-229.

Eberhardt, J. L. (2005). Imaging race. American Psychologist, 60, 181-190.

Ellemers, N. (2012). The group self. science, 336(6083), 848-852.

Ellemers, N., Spears, R., \& Doosje, B. (2002). Self and Social Identity*. Annual review of psychology, 53(1), 161-186.

Eres, R., \& Molenberghs, P. (2013). The influence of group membership on the neural correlates involved in empathy. Frontiers in human neuroscience, 7.

Fehr, E., Bernhard, H., \& Rockenbach, B. (2008). Egalitarianism in young children. Nature, 454(7208), 1079-1083.

Fazio, R.H., Jackson, J.R., Dunton, B.C., \& Williams, C.J. (1995). Variability in automatic activation as an unobtrusive measure of racial attitudes: A bona fide pipeline? Journal of Personality and Social Psychology, 69, 1013-1027.

Feingold CA (1914) The influence of environment on identification of persons and things. Journal of Criminal Law and Police Science 5:39-51

Festinger, L. (1954). A theory of social comparison processes. Human Relations, 7, 117-140.

Fiske, A.P. (1992). The four elementary forms of sociality: Framework for a unified theory of social relations. Psychological Review, 99(4), 689-723.

Fiske, S.T. (2011). Envy Up, Scorn Down: How Status Divides Us. New York: Russell Sage Foundation.

Fiske, S. T., Cuddy, A. J. C., \& Glick, P. (2007). Universal dimensions of social cognition: warmth and competence. Trends in Cognitive Sciences, 11, 77-83.

Fiske, S. T., Cuddy, A. J. C., Glick, P., \& Xu, J. (2002). A model of (often mixed) stereotype content: Competence and warmth respectively follow from perceived status and competition. Journal of Personality and Social Psychology, 82, 878-902.

Fiske, S. T., \& Neuberg, S. L. (1990). A continuum of impression formation, from categorybased to individuating processes: Influences of information and motivation on attention and interpretation. In M. P. Zanna (Ed.), Advances in experimental social psychology (Vol. 23, pp. 1-74). New York: Academic Press.

Fiske, S. T., \& Ruscher, J. B. (1993). Negative interdependence and prejudice: Whence the affect? In D. M. Mackie \& D. L. Hamilton (Eds.), Affect, cognition, and stereotyping: Interactive processes in group perception (pp. 239-268). San Diego, CA: Academic Press.

Flinn, M. V., Ponzi, D., \& Muehlenbein, M. P. (2012). Hormonal mechanisms for regulation of aggression in human coalitions. Human Nature, 23(1), 68-88.

Forbes, C. E., Cox, C. L., Schmader, T., \& Ryan, L. (2012). Negative stereotype activation alters interaction between neural correlates of arousal, inhibition and cognitive control. Social Cognitive and Affective Neuroscience,7(7), 771-781.

Forbes, C. E., Poore, J. C., Barbey, A. K., Krueger, F., Solomon, J., Lipsky, R. H., Hodgkinson, C. A., Goldman, D., \& Grafman, J. (2011). BDNF polymorphism-dependent OFC and 
DLPFC plasticity differentially moderates implicit and explicit bias. Cerebral Cortex, 22(11), 2602-2609.

Forbes, C. E., \& Grafman, J. (2010). The Role of the Human Prefrontal Cortex in Social Cognition and Moral Judgment. Annual Review of Neuroscience, 33, 299- 324.

Forgiarini, M., Galluci, M., \& Maravita, A. (2011). Racism and the empathy for pain on our skin. Frontiers in Psychology, 2, 108. doi: 10.3389/fpsyg.2011.00108

Freeman, J. B., \& Ambady, N. (2011). A dynamic interactive theory of person construal. Psychological Review, 118(2), 247.

Friston, K.J. and Buchel, C. (2003) Functional connectivity. In Human Brain Function (2nd edn) (Frackowiak, R.S.J. et al., eds), Academic Press.

Gaertner, S. L. \& Dovidio, J. F. (2000). Reducing Intergroup Bias: The Common In-group Identity Model. Philadelphia, PA: Psychology Press.

Gaertner, S. L., Mann, J., Murrell, A., \& Dovidio, J. F. (1989). Reducing intergroup bias: The benefits of recategorization. Journal of Personality and Social Psychology, 57(2), 239.

Gaertner, L., \& Schopler, J. (1998). Perceived in-group entitativity and intergroup bias: An interconnection of self and others. European Journal of Social Psychology, 28, 963-980.

Gauthier, I., Tarr, M. J., Anderson, A. W., Skudlarski, P., \& Gore, J. C. (1999). Activation of the middle fusiform 'face area' increases with expertise in recognizing novel objects. Nature Neuroscience, 2, 568-573.

Gibbons, F. X. \& Gerrard, M. (1991). Downward comparison and coping with threat. In J. Suls \& T. A. Wills (Eds.), Social comparison: Contemporary theory and research. (pp.317346). Hillsdale, NJ: Erlbaum.

Gilbert, D. T., Giesler, R. B., \& Morris, K. A. (1995). When comparisons arise.Journal of personality and social psychology, 69(2), 227.

Gladue, B. A., Boechler, M., \& McCaul, K. D. (1989). Hormonal response to competition in human males. Aggressive Behavior, 15, 409-422.

Glick, P. (2002). Sacrificial lambs in wolves clothing: Envious prejudice, ideology, and scapegoating of Jews. In L. S. Newman \& R. Erber (Eds.), What social psychology can tell us about the Holocaust (pp. 113-142). Oxford, United Kingdom: Oxford University Press.

Golby, A. J., Gabrieli, J. D. E., Chiao, J. Y., \& Eberhardt, J. L. (2001). Differential fusiform responses to same- and other-race faces. Nature Neuroscience, 4, 845-850.

Goette, L., Huffman, D., Meier, S., \& Sutter, M. (2012). Competition Between Organizational Groups: Its Impact on Altruistic and Antisocial Motivations. Management Science, 58, 948-960.

Grabenhorst, F., \& Rolls, E.T. (2011). Value, pleasure and choice in the ventral prefrontal cortex. Trends in Cognitive Science, 15(2), 56-67.

Greenwald, A. G., McGhee, D. E., \& Schwartz, J. L. K. (1998). Measuring individual differences in implicit cognition: The Implicit Association Test. Journal of Personality and Social Psychology, 74, $1464-1480$.

Gutsell, J. N., \& Inzlicht, M. (2010). Empathy constrained: Prejudice predicts reduced mental simulation of actions during observation of out-groups. Journal of Experimental Social Psychology, 46(5), 841-845.

Gutsell, J. N., \& Inzlicht, M. (2012). Intergroup differences in the sharing of emotive states: Neural evidence of an empathy gap. Social Cognitive Affective Neuroscience, 7, 596603. doi: 10.1093/scan/nsr035 
Gutsell, J.N., \& Inzlicht, M. (2013). Using EEG mu-suppression to explore group biases in motor resonance. In B. Derks, D. Scheepers and N. Ellemers (Eds.). The Neuroscience of Prejudice (pp. 278-298). London: Psychology Press.

Hackel, L.M., Looser, C.E., \& Van Bavel, J.J. (2013). Group membership alters the threshold for mind perception: The role of social identity, collective identification, and intergroup threat. Journal of Experimental Social Psychology.

Hackman, J. R., \& Katz, N. (2010). Group behavior and performance.Handbook of social psychology.

Hamann, S. B., Ely, T. D., Grafton, S. T., \& Kilts, C. D. (1999). Amygdala activity related to enhanced memory for pleasant and aversive stimuli. Nature Neuroscience, 2(3), 289-293.

Hamilton, D. L., \& Sherman, S. J. (1996). Perceiving persons and groups. Psychological Review, 103, 336-355.

Hein, G., Silani, G., Preuschoff, K., Batson, C. D., \& Singer, T. (2010). Neural responses to ingroup and out-group members' suffering predict individual differences in costly helping. Neuron, 68(1), 149-160.

Harris, L. T., \& Fiske, S. T. (2006). Dehumanizing the lowest of the low neuroimaging responses to extreme out-groups. Psychological Science, 17(10), 847-853.

Harris, L. T., \& Fiske, S. T. (2009). Social neuroscience evidence for dehumanised perception. European review of social psychology, 20(1), 192-231.

Hart, A. J., Whalen, P. J., Shin, L. M., McInerney, S. C., Fischer, H., \& Rauch, S. L. (2000). Differential response in the human amygdala to racial out-group versus in-group face stimuli. Neuroreport, 11, 2351-2355.

Hasson, U., Ghazanfar, A. A., Galantucci, B., Garrod, S., \& Keysers, C. (2012). Brain-to-brain coupling: a mechanism for creating and sharing a social world. Trends in cognitive sciences, 16(2), 114-121.

Hehman, E., Maniab, E. W., \& Gaertner, S. L. (2010). Where the division lies: Common ingroup identity moderates the cross-race facial-recognition effect. Journal of Experimental Social Psychology, 46, 445-448.

Heinrichs, M., von Dawans, B., \& Domes, G. (2009). Oxytocin, vasopressin, and human social behavior. Frontiers in Neuroendocrinology, 30(4), 548-557.

Hewstone, M., Rubin, M., \& Willis, H. (2002). Intergroup bias. Annual review of psychology, 53(1), 575-604.

Hirschenhauser, K., \& Oliveira, R. F. (2006). Social modulation of androgens in male vertebrates: meta-analyses of the challenge hypothesis. Animal Behavior, 71, 265-277.

Hogg, M. A. (1992). The social psychology of group cohesiveness: From attraction to social identity. London: Harvester Wheatsheaf.

Hogg, M. A. (1993). Group cohesiveness: A critical review and some new directions. European Review of Social Psychology, 4, 85-111.

Hogg, M. A. (2000). Subjective uncertainty reduction through self-categorization: A motivational theory of social identity processes. European review of social psychology, 11(1), 223-255.

Holyoak, K. J., \& Gordon, P. C. (1983) Social reference points. Journal of Personality and Social Psychology, 44, 881-887.

Honey, C.J., Thesen, T., Donner, T.H., Silbert, L.J., Carlson, C.E., Devinsky, O., Doyle, W.K., Rubin, N., Heeger, D.J., Hasson, U. (2012) Slow cortical dynamics and the accumulation of information over long time scales. Neuron 76:423-434. 
Hugenberg, K., Young, S. G., Bernstein, M. J., \& Sacco, D. F. (2010). The CategorizationIndividuation Model: An integrative account of the other-race recognition deficit. Psychological Review, 117(4), 1168-1187.

Hughes, R. (2007). Neotic preferences in laboratory rodents: issues, assessment and substrates. Neuroscience and Biobehavioral Reviews, 31, 441-464.

Hugh-Jones, D., \& Leroch, M. A., (2011). "Reciprocity towards Groups," CAGE Online Working Paper Series 51, Competitive Advantage in the Global Economy (CAGE).

Insko, C. A., \& Schopler, J. (1998). Differential distrust of groups and individuals. In C. Sedikides, J. Schopler, \& C. A. Insko (Eds.), Intergroup cognition and intergroup behavior (pp. 75-108). Mahwah, NJ:Erlbaum.

Insko, C. A., Wildschut, T., \& Cohen, T. R. (2013). Interindividual-intergroup discontinuity in the prisoner's dilemma game: How common fate, proximity, and similarity affect intergroup competition. Organizational Behavior and Human Decision Processes, 120(2), 168-180.

Ito, T. A., \& Bartholow, B. D. (2009). The neural correlates of race. Trends in cognitive sciences, 13(12), 524-531.

Ito, T. A., \& Urland, G. R. (2003). Race and gender on the brain: Electrocortical measures of attention to the race and gender of multiply categorizable individuals. Journal of Personality \& Social Psychology, 85(4), 616-626.

Ito, T. A., \& Urland, G. R. (2005). The influence of processing objectives on the perception of faces: An ERP study of race and gender perception. Cognitive, Affective, and Behavioral Neuroscience, 5, 21-36.

Jenkins, A. C., \& Mitchell, J. P. (2011). Medial prefrontal cortex subserves diverse forms of selfreflection. Social neuroscience, 6(3), 211-218.

Jetten, J., Spears, R., \& Postmes, T. (2004). Intergroup distinctiveness and differentiation: a meta-analytic integration. Journal of personality and social psychology, 86(6), 862.

Johnson, D. W., \& Johnson, R. T. (1989). Cooperation and competition: Theory and research. Edina, MN: Interaction.

Johnson, J., Simmons, C., Jordan, A., MacLean, L., Taddei, J., \& Thomas, D. (2002). Rodney King and O. J. revisited: The impact of race and defendant empathy induction on judicial decisions. Journal of Applied Social Psychology, 32, 1208-1223.

Jost, J. T., \& Amodio, D. M. (2012). Political ideology as motivated social cognition: Behavioral and neuroscientific evidence. Motivation and Emotion,36(1), 55-64.

Jost, J.T., \& Banaji, M.R. (1994). The role of stereotyping in system-justification and the production of false consciousness. British Journal of Social Psychology, 33(1), 1-27.

Kable, J.W., \& Glimcher, P.W. (2009). The neurobiology of decision: Consensus and controversy. Neuron, 63, 733-745.

Kanwisher, N., McDermott, J., \& Chun, M. (1997). The Fusiform Face Area: A module in human extrastriate cortex specialized for the perception of faces. Journal of Neuroscience, $17,4302-4311$.

Karylowski, J. I. (1990). Social reference points and accessibility of trait-related information in self-other similarity judgments. Journal of Personality and Social Psychology, 58, 975983.

Kelley, W. M., Macrae, C. N., Wyland, C. L., Caglar, S., Inati, S., \& Heatherton, T. F. (2002). Finding the self? An event-related fMRI study. Journal of cognitive neuroscience, 14(5), 785-794. 
Kiehl, K.A., Laurens, K.R., Duty, T.L., Forster, B.B., \& Liddle, P.F. (2001). Neural sources involved in auditory target detection and novelty processing: An event-related fMRI study. Psychophysiology, 38, 133-142.

Knutson, B., Cooper, J. C. (2005). Functional magnetic resonance imaging of reward prediction. Current Opinion in Neurology, 18, 411-417.

Koenigs, M., Young, L., Adolphs, R., Tranel, D., Cushman, F., Hauser, M., \& Damasio, A. (2007). Damage to the prefrontal cortex increases utilitarian moral judgements. Nature, 446(7138), 908-911.

Kubota, J. T., Banaji, M. R., \& Phelps, E. A. (2012). The neuroscience of race.Nature neuroscience, 15(7), 940-948.

Kurzban, R., \& Neuberg, S. (2005). Managing Ingroup and Outgroup Relationships. In Buss, David M. (Ed) The handbook of evolutionary psychology, (pp. 653-675). Hoboken, NJ: John Wiley \& Sons Inc

Kurzban, R., Tooby, J., \& Cosmides, L. (2001). Can race be erased? Coalitional computation and social categorization. Proceedings of the National Academy of Sciences, 98, 15387-15392.

LeDoux, J. E. (1996). The emotional brain: The mysterious underpinnings of emotional life. New York; Toronto: Simon \& Schuster.

Lerner, Y., Honey, C.J., Silbert, LJ, Hasson, U. (2011) Topographic mapping of a hierarchy of temporal receptive windows using a narrated story. Journal of Neuroscience 31(8):29062915.

Levin, D. T. (1996). Classifying faces by race: The structure of face categories. Journal of Experimental Psychology: Learning, Memory, and Cognition, 22, 1364-1382.

Levin, D.T. (2000) Race as a visual feature: Using visual search and perceptual discrimination tasks to understand face categories and the cross-race recognition deficit. Journal of Experimental Psychology, 129(4), 559-574.

Levine, J. M., \& Moreland, R. L. (1990). Progress in small group research.Annual review of psychology, 41(1), 585-634.

Levy, D.J. \& Glimcher, P.W. (2012). The root of all value: A neural common currency for choice. Current Opinion in Neurobiology, 22(6) 1027-1038

Lewis, G. J., \& Bates, T. C. (2010). Genetic evidence for multiple biological mechanisms underlying in-group favoritism. Psychological science, 21(11), 1623-1628.

Lewis, G.J., Kandler, C., \& Riemann, R. (2013). Distinct heritable influences underpin in-group love and out-group derogation. Social Psychological and Personality Science

Lickel, B., Miller, N., Stenstrom, D. M., Denson, T. F., \& Schmader, T. (2006). Vicarious retribution: The role of collective blame in intergroup aggression.Personality and Social Psychology Review, 10(4), 372-390.

Lieberman, M. D., Hariri, A., Jarcho, J. M., Eisenberger, N. I., \& Bookheimer, S. Y. (2005). An fMRI investigation of race-related amygdala activity in African-American and Caucasian-American individuals. Nature neuroscience, 8(6), 720-722.

Ly, M., Haynes, M. R., Barter, J. W., Weinberger, D. R., \& Zink, C. F. (2011). Subjective socioeconomic status predicts human ventral striatal responses to social status information. Current biology, 21(9), 794-797.

Mahajan, N., Martinez, M. A., Gutierrez, N. L., Diesendruck, G., Banaji, M. R., \& Santos, L. R. (2011). The evolution of intergroup bias: perceptions and attitudes in rhesus macaques. Journal of personality and social psychology,100(3), 387. 
Malpass, R. S., \& Kravitz, J. (1969). Recognition for faces of own and other race. Journal of personality and social psychology, 13(4), 330.

Mason, M. F., Norton, M. I., Van Horn, J. D., Wegner, D. M., Grafton, S. T., and Macrae, C. N. (2007). Wandering minds: the default network and stimulus-independent thought. Science, 315, 393-395.

Mather, M., Cacioppo, J. T., \& Kanwisher, N. (2013). How fMRI can inform cognitive theories. Perspectives on Psychological Science, 8(1), 108-113.

Mathur, V. A., Harada, T., Lipke, T., \& Chiao, J. Y. (2010). Neural basis of extraordinary empathy and altruistic motivation. Neuroimage, 51(4), 1468-1475.

Mathur, V. A., Harada, T., \& Chiao, J. Y. (2012). Racial identification modulates default network activity for same and other races. Human brain mapping, 33(8), 1883-1893.

Meier, B. P., \& Hinsz, V. B. (2004). A comparison of human aggression committed by groups and individuals: An interindividual-intergroup discontinuity. Journal of Experimental Social Psychology, 40, 551-559.

Meissner, C. A., \& Brigham, J. C. (2001). Thirty years of investigating the own-race bias in memory for faces: A meta-analytic review. Psychology, Public Policy, and Law, 7(1), 3.

Mende-Siedlecki, P., Cai, Y., \& Todorov, A. (2012). The Neural Dynamics of Updating Person Impressions. Social Cognitive and Affective Neuroscience, [Epub ahead of print; doi: $10.1093 / \mathrm{scan} / \mathrm{nss} 040]$.

Milne, E., \& Grafman, J. (2001). Ventromedial prefrontal cortex lesions in humans eliminate implicit gender stereotyping. Journal of Neuroscience,21(12), 1-6.

Mitchell, J. P. (2009). Social psychology as a natural kind. Trends in cognitive sciences, 13(6), 246-251.

Mitchell, J. P., Ames, D. L., Jenkins, A. C., \& Banaji, M. R. (2009). Neural correlates of stereotype application. Journal of Cognitive Neuroscience, 21(3), 594-604.

Mitchell, J. P., Macrae, C. N., \& Banaji, M. R. (2006). Dissociable medial prefrontal contributions to judgments of similar and dissimilar others. Neuron, 50, 655-663.

Molenberghs, P. (2013). The neuroscience of in-group bias. Neuroscience and Biobehavioral Reviews, 37: 1530-1536.

Molenberghs, P., Halász, V., Mattingley, J. B., Vanman, E. J., \& Cunnington, R. (2012). Seeing is believing: Neural mechanisms of action-perception are biased by team membership. Human Brain Mapping.

Molenberghs, P. \& Morrison, S. (epub ahead of print). The role of the medial prefrontal cortex in social categorization. Social Cognitive and Affective Neuroscience, doi:10.1093/scan/nss135.

Montague, P.R., \& Berns, G.S. (2002) Neural economics and the biological substrates of valuation. Neuron, 36, 265-284.

Moran, J. M., Young, L. L., Saxe, R., Lee, S. M., O'Young, D., Mavros, P. L., \& Gabrieli, J. D. (2011). Impaired theory of mind for moral judgment in high-functioning autism. Proceedings of the National Academy of Sciences, 108(7), 2688-2692.

Moreland, R. L., Hogg, M. A., \& Hains, S. C. (1994). Back to the future: Social psychological research on groups. Journal of Experimental Social Psychology,30(6), 527-555.

Morrison, S., Decety, J. \& Molenberghs, P. (2012). The neuroscience of group membership. Neuropsychologia, 50 (8), 2114-2120

Mullen, B., Brown, R., \& Smith, C. (1992). In-group bias as a function of salience, relevance, and status: an integration. European Journal of Social Psychology, 22, 103-122. 
Mussweiler, T., \& Bodenhausen, G. V. (2002). I know you are, but what am I? Self-evaluative consequences of judging in-group and out-group members. Journal of Personality and Social Psychology, 82, 19-32.

Neuberg. S. L., \& Cottrell, C. A. (2006). Evolutionary bases of prejudices. In M. Schaller, J. A. Simpson, \& D. T. Kenrick (eds.), Evolution and social psychology (pp. 163-187). New York: Psychology Press.

Ochsner, K. N., \& Lieberman, M. D. (2001). The emergence of social cognitive neuroscience. American Psychologist, 56(9), 717.

Ochsner, K.N., Ray, R.D., Robertson, E.R., Cooper, J.C., Chopra, S., Gabrieli, J.D.E., \& Gross, J.J. (2004). For better or for worse: Neural systems supporting the cognitive down- and up-regulation of negative emotion. Neuroimage, 23(2), 483-499.

O'Doherty, J. (2004). Reward representations and reward-related learning in the human brain: Insights from human neuroimaging. Current Opinion in Neurobiology, 14(6), 769-776.

Olson, J. M., Herman, C. P., Zanna, M. P. (1986). Relative Deprivation and Social Comparison. Hillsdale, NJ: Lawrence Erlbaum.

Otten, S., \& Wentura, D. (1999). About the impact of automaticity in the Minimal Group Paradigm: Evidence from affective priming tasks. European Journal of Social Psychology, 29(8), 1049-1071.

Packer, D. J. \& Van Bavel, J. J. (in press). The dynamic nature of identity: From the brain to behavior. In N. Branscombe \& K. Reynolds. (Eds.) The Psychology of Change: Life Contexts, Experiences, and Identities. Psychology Press.

Pelham, B. W., \& Wachsmuth, J. 0. (1995). The waxing and waning of the social self: Assimilation and contrast in social comparison. Journal of Personality and Social Psychology, 69, 825-838.

Pemberton, M. B., Insko, C. A., \& Schopler, J. (1996). Memory for and experience of differential competitive behavior of individuals and groups. Journal of Personality and Social Psychology, 71, 953-966.

Peters, J., \& Büchel, C. (2010). Episodic future thinking reduces reward delay discounting through an enhancement of prefrontal-mediotemporal interactions. Neuron, 66(1), 138148.

Phelps, E. A. (2006). Emotion and cognition: Insights from studies of the human amygdala. Annual Review of Psychology, 24 (57), 27-53.

Phelps, E. A., Cannistraci, C. J., \& Cunningham, W . A. (2003). Intact performance on an indirect measure of race bias following amygdala damage.Neuropsychologia, 41(2), 203-208.

Phelps, E. A., O'Connor, K. J., Cunningham, W. A., Funayama, E. S., Gatenby, J. C., Gore, J. C. (2000). Performance on indirect measures of race evaluation predicts amygdala activation. Journal of Cognitive Neuroscience, 12, 729-738.

Phelps, E. A., \& Thomas, L. A. (2003). Race, behavior and the brain: The role of neuroimaging in understanding complex human behaviors. Political Psychology, 24, 747-758.

Phillips, C.G., Zeki, S., Barlow, H.B. (1984). Localisation of function in the cerebral cortex: Past, present and future. Brain, 107,327-361.

Poldrack, R. A. (2006). Can cognitive processes be inferred from neuroimaging data?. Trends in cognitive sciences, 10(2), 59-63.

Preston, S. D., \& de Waal, F. B. M. (2001). Empathy: Its ultimate and proximate bases. Behavioral and Brain Sciences, 25, 1-20. 
Pyles, J. A., Verstynen, T. D., Schneider, W., \& Tarr, M. J. (2013). Explicating the Face Perception Network with White Matter Connectivity. PloS one, 8(4), e61611.

Raichle M.E., MacLeod, A.M., Snyder, A.Z., Powers,W.J,, Gusnard,D.A., Shulman, G.L. (2001) A default mode of brain function. Proceedings of the National Academy of Sciences, 98, 676-682.

Rand, D. G., Pfeiffer, T., Dreber, A., Sheketoff, R. W., Wernerfelt, N. C., \& Benkler, Y. (2009). Dynamic remodeling of in-group bias during the 2008 presidential election. Proceedings of the National Academy of Sciences,106(15), 6187-6191.

Ranganath, C., Rainer, G. (2003). Neural mechanisms for detecting and remembering novel events. Nature Reviews Neuroscience, 4, 193-202

Ratner, K. G., \& Amodio, D. M. (2012). Seeing "us vs. them": Minimal group effects on the neural encoding of faces. Journal of Experimental Social Psychology.

Ratner, K. G., \& Kubota, J. T. (2012). Genetic contributions to intergroup responses: a cautionary perspective. Frontiers in Human Neuroscience, 6.

Redcay, E., Dodell-Feder, D., Pearrow, M. J., Mavros, P. L., Kleiner, M., Gabrieli, J. D., \& Saxe, R. (2010). Live face-to-face interaction during fMRI: a new tool for social cognitive neuroscience. Neuroimage, 50(4), 1639-1647.

Rhodes, G., Byatt, G., Michie, P. T., \& Puce, A. (2004). Is the fusiform face area specialized for faces, individuation, or expert individuation? Journal of Cognitive Neuroscience, 16, 189-203.

Richeson, J.A., Baird, A.A., Gordon, H.L., Heatherton, T.F, Wyland, C.L., Trawalter, S., \& Shelton, J.N. (2003). An MRI investigation of the impact of interracial contact on executive function. Nature Neuroscience, 6, 1323-1328.

Rilling, J.K., Dagenais, J.E., Goldsmith, D.R., Glenn, A.L., \& Pagnoni, G. (2008). Social cognitive neural networks during in-group and out-group interactions. Neuroimage, 41(4), 1447-1461.

Rilling, J.K., Gutman, D.A., Zeh, T.R., Pagnoni, G., Berns, G.S., \& Kilts, C.D. (2002). Neural basis of social cooperation.Neuron, 35, 395-405.

Rilling, J. K., \& Sanfey, A. G. (2011). The neuroscience of social decision-making. Annual review of psychology, 62, 23-48.

Rizzolatti, G., \& Fabbri-Destro, M. (2008). The mirror system and its role in social cognition. Current Opinions in Neurobiology, 18: 179-184.

Rizzolatti, G., \& Craighero, L. (2004). The mirror-neuron system. Annual Review of Neuroscience, 27, 169-192.

Robinson, G. E., Fernald, R. D., \& Clayton, D. F. (2008). Genes and social behavior. science, 322(5903), 896-900.

Rudman, L., A., \& Farichild, K. (2004). Reactions to counterstereotypic behavior: The role of backlash in cultural stereotype maintenance. Journal of Personality and Social Psychology, 87, 157-176.

Salvador, A. (2005). Coping with competitive situations in humans. Neuroscience and Biobehavioral Reviews, 29, 195-205.

Sangrigoli, S., Pallier, C., Argenti, A. M., Ventureyra, V. A. G., \& De Schonen, S. (2005). Reversibility of the other-race effect in face recognition during childhood. Psychological Science, 16(6), 440-444.

Saxe, R., \& Kanwisher, N. (2003). People thinking about thinking people: The role of the temporo-parietal junction in "theory of mind." Neuroimage, 19, 1835-1842. 
Scheepers, D. (2009). Turning social identity threat into challenge: Status stability and cardiovascular reactivity during inter-group competition. Journal of Experimental Social Psychology, 45, 228.

Scheepers, D., Derks, B., Nieuwenhuis, S., Lelieveld, G. J., Van Nunspeet, F., Rombouts, S. A., \& De Rover, M. (2013). The Neural Correlates of In-group and Self-Face Perception: Is There Overlap for High Identifiers?. Frontiers in Human Neuroscience, 7, 528.

Scheepers, D., \& Ellemers, N. (2005). When the pressure is up: The assessment of social identity threat in low and high status groups. Journal of Experimental Social Psychology, 41(2), 192-200.

Schilbach, L., Eickhoff, S. B., Rotarska-Jagiela, A., Fink, G. R., \& Vogeley, K. (2008). Minds at rest? Social cognition as the default mode of cognizing and its putative relationship to the "default system" of the brain. Consciousness and cognition, 17(2), 457-467.

Schilbach, L., Timmermans, B., Reddy, V., Costall, A., Bente, G., Schlicht, T., \& Vogeley, K. (2012). Toward a second-person neuroscience. Behavioral and Brain Sciences. Epub ahead of print.

Segerstrom, S. C., \& Miller, G. E. (2004). Psychological stress and the human immune system: a meta-analytic study of 30 years of inquiry. Psychological bulletin, 130(4), 601.

Shamay-Tsoory, S.G., Abu-Akel, A., Palgi, S., Sulieman, R., Fischer-Shofty, M., Levkovitz, Y., \& Decety, J. (2013). Giving peace a chance: Oxytocin increases empathy to pain in the context of the Israeli-Palestinian conflict. Psychoneuroendocrinology, 38(12), 3139-3144.

Sherif, M. (1966) In common predicament: Social psychology of intergroup conflict and cooperation, Boston: Houghton-Mifflin.

Sherif, M., Harvey, O. J., White, B. J., Hood, W. R., \& Sherif, C. W. (1961). Intergroup cooperation and competition: The Robbers Cave experiment. Norman, OK: University Book Exchange.

Sherif, M., \& Hovland, C. I. (1961). Social judgment. New Haven, CT: Yale University Press.

Sidanius, J. \& Pratto, F. (1999). Social Dominance: An Intergroup Theory of Social Hierarchy and Oppression. New York: Cambridge University Press.

Sidanius, J. \& Pratto, F. (2001). Social dominance: An intergroup theory of social heirarchy and oppression. Cambridge University Press.

Singer, T., Seymour, B., O’Doherty, J. P., Stephan, K. E., Dolan, R. J., \& Frith, C. D. (2006). Empathic neural responses are modulated by the perceived fairness of others. Nature, 439, 466-469.

Smith, E. R., Coats, S., \& Walling, D. (1999). Overlapping mental representations of self, ingroup, and partner: Further response time evidence and a connectionist model. Personality \& Social Psychology Bulletin, 25(7), 873-882.

Smith, E. R., \& Henry, S. (1996). An in-group becomes part of the self: Response time evidence. Personality \& Social Psychology Bulletin, 22(6), 635-642.

Sporer, S. L. (2001). Recognizing faces of other ethnic groups: An integration of theories. Psychology, Public Policy, and Law, 7, 36-97.

Squire, L.R., Stark, C.E., Clark, R.E. (2004) The medial temporal lobe. Annual Review of Neuroscience, 27, $279-306$.

Srull, T. K., \& Gaelick, L. (1983). General principles and individual differences in the self as a habitual reference point: An examination of self-other judgments of similarity. Social Cognition, 2, 108-121. 
Struch, N, \& Schwartz, S. H. (1989). Intergroup aggression: Its predictors and distinctness from in-group bias. Journal of Personality and Social Psychology, 56, 364-373.

Suls, J., \& Wheeler, L. (Eds.). (2000). Handbook of social comparison: Theory and research. New York: Kluwer Academic/Plenum Publishers.

Tajfel, H. (1970). Experiments in intergroup discrimination. Scientific American,223(5), 96-102.

Tajfel, H. (1982). Social psychology of intergroup relations. Annual review of psychology, 33(1), 1-39.

Tajfel, H., Billig, M., Bundy, R., \& Flament, C. (1971). Social categorization and intergroup behaviour. European Journal of Social Psychology, 1, 149-178.

Tajfel, H., \& Turner, J. (1979). An integrative theory of intergroup conflict. In W. G. Austin \& S. Worschel (Eds.), The Social Psychology of Intergroup Relations (pp. 33-47). Pacific Grove, CA: Brooks/Cole Publishing.

Tarr, M.J., \& Gauthier, I. (2000). FFA: A flexible fusiform area for subordinate-level visual processing automatized by expertise. Nature Neuroscience, 3(8), 764-769.

Taylor, S. E., Fiske, S. T., Etcoff, N. L., \& Ruderman, A. (1978). Categorical and contextual bases of person memory and stereotyping. Journal of Personality and Social Psychology, 36, 778-793.

Terbeck, S., Kahane, G., McTavish, S., Savulescu, J., Cowen, P. J., \& Hewstone, M. (2012). Propranolol reduces implicit negative racial bias. Psychopharmacology, 222, 419-424.

Tesser, A., Millar, M. \& Moore, J. (1988). Some affective consequences of social comparison and reflection processes: The pain and pleasure of being close. Journal of Personality and Social Psychology, 54, 49-61.

Thomsen, L., Franeknhuis, W.E., Ingold-Smith, M., Carey, S. (2011). Big and mighty: preverbal infants mentally represent social dominance. Science, 331(6016), 477- 80.

Tricomi, E., Rangel, A., Camerer, C. F., \& O’Doherty, J. P. (2010). Neural evidence for inequality-averse social preferences. Nature, 463(7284), 1089-1091.

Turner, J. C., Hogg, M. A., Oakes, P. J., Reicher, S. D., \& Wetherell, M. S. (1987). Rediscovering the social group: A Self-Categorization Theory. Oxford: Basil Blackwell.

Turner, J. C., Oakes, P. J., Haslam, S. A., \& McGarty, C. (1994). Self and collective: Cognition and social context. Personality and Social Psychology Bulletin, 20(5), 454-463.

Van Bavel, J.J., \& Cunningham, W.A. (2009). Self-categorization with a novel mixed-race group moderates automatic social and racial biases. Personality and Social Psychology Bulletin, 35(3), 321-335.

Van Bavel, J. J., \& Cunningham, W. A. (2011). A social neuroscience approach to self and social categorisation: A new look at an old issue. European Review of Social Psychology, 21(1), 237-284. doi: 10.1080/10463283.2010.543314

Van Bavel, J. J., \& Cunningham, W. A. (2012). A social identity approach to person memory: Group membership, collective identification, and social role shape attention and memory. Personality and Social Psychology Bulletin, 38, 1566-1578. doi: doi: 10.1177/0146167212455829

Van Bavel, J. J., Earls, H., Morris, J. \& Cunningham, W. A. (2013). Group membership overrides early racial bias: An ERP investigation. Unpublished manuscript. New York University.

Van Bavel, J. J., Packer, D. J., \& Cunningham, W. A. (2008). The neural substrates of in-group bias: A functional magnetic resonance imaging investigation. Psychological Science, 19, 1131-1139. 
Van Bavel, J. J., Packer, D. J., \& Cunningham, W. A. (2011). Modulation of the Fusiform Face Area following minimal exposure to motivationally relevant faces: Evidence of in-group enhancement (not out-group disregard). Journal of Cognitive Neuroscience, 23(11), 3343-3354.doi: 10.1162/jocn_a_00016

Van Bavel, J. J., Swencionis, J. K., O'Connor, R. C., \& Cunningham, W. A. (2012). Motivated social memory: Belonging needs moderate the own-group bias in face recognition.

Journal of Experimental Social Psychology, 48(3), 707-713. doi: 10.1016/j.jesp.2012.01.006

Vincent, J. L., Kahn, I., Snyder, A. Z., Raichle, M. E., \& Buckner, R. L. (2008). Evidence for a frontoparietal control system revealed by intrinsic functional connectivity. Journal of neurophysiology, 100(6), 3328-3342.

Volz, K. G., Kessler, T., \& von Cramon, D. Y. (2009). In-group as part of the self: In-group favoritism is mediated by medial prefrontal cortex activation.Social Neuroscience, 4(3), 244-260.

Vuilleumier, P. (2005). How brains beware: Neural mechanisms of emotional attention. Trends in Cognitive Sciences, 9, 585-594.

Vuilleumier, P., \& Brosch, T. (2009). Interactions of emotion and attention in perception. In M. S. Gazzaniga (Ed.), The cognitive neurosciences IV (pp. 925-934). Cambridge. MA: MIT Press.

Waytz, A., \& Young, L. (2012). The Group-Member Mind Trade-Off Attributing Mind to Groups Versus Group Members. Psychological Science, 23(1), 77-85.

Wedell, D. H. (1994). Contextual contrast in evaluative judgments: A test of pre- versus postintegration models of contrast. Journal of Personality and Social Psychology, 66, $1007-1019$.

Wilson, D.S., \& Wilson, E.O. (2007). Rethinking the theoretical foundation of sociobiology. Quarterly Review of Biology, 82, 327-348.

Wingfield, J. C., Hegner, R. E., Dufty, A. M., Jr., \& Ball, G. F. (1990). The “challenge hypothesis": theoretical implications for patterns of testosterone secretion, mating systems, and breeding strategies. American Naturalist, 136, 829-846.

Whalen, P. J. (1998). Fear, vigilance and ambiguity: Initial neuroimaging studies of the human amygdala. Current Directions in Psychological Science, 7, 177-188.

Whalen, P. J., Rauch, S. L., Etcoff, N. L., McInerney, S. C., Lee, M., \& Jenike, M. A. (1998). Masked presentations of emotional facial expressions modulate amygdala activity without explicit knowledge. Journal of Neuroscience, 18, 411-418.

Wheeler, M. E., \& Fiske, S. T. (2005). Controlling racial prejudice: Social-cognitive goals affect amygdala and stereotype activation. Psychological Science, 16(1), 56-63.

Wildschut, T., Pinter, B., Vevea, J. L., Insko, C. A., \& Schopler, J. (2003). Beyond the group mind: A quantitative review of the interindividual intergroup discontinuity effect. Psychological Bulletin, 129, 698-722.

Wilson, E. (1998). 0.(1998). Consilience: The unity of knowledge.

Wobber, V., Hare, B., Maboto, J., Lipson, S., Wrangham, R., \& Ellison, P. T. (2010). Differential changes in steroid hormones before competition in bonobos and chimpanzees. Proceedings of the National Academy of Sciences USA, 107, 12457-12462.

Woolf, L. M., \& Hulsizer, M. R. (2004). Hate groups for dummies: How to build a successful hate group. Humanity and Society, 28(1), 40-62. 
Xiao, Y.J., \& Van Bavel, J.J. (2012). See your friends close, and your enemies closer: Social identity and identity threat shape the representation of physical distance. Personality and Social Psychology Bulletin, 38, 959-972.

Xu, X., Zuo, X., Wang, X., \& Han, S. (2009). Do you feel my pain? Racial group membership modulates empathic neural responses. Journal of Neuroscience, 29, 8525-8529.

Yamada, M., \& Decety, J. (2009). Unconscious affective processing and empathy: An investigation of subliminal priming on the detection of painful facial expressions. Pain, 143, 71-75.

Young, L., Bechara, A., Tranel, D., Damasio, H., Hauser, M., \& Damasio, A. (2010a). Damage to ventromedial prefrontal cortex impairs judgment of harmful intent. Neuron, 65(6), 845-851.

Young, L., Camprodon, J., Hauser, M., Pascual-Leone, A., Saxe, R. (2010b). Disruption of the right temporoparietal junction with transcranial magnetic stimulation reduces the role of beliefs in moral judgments. PNAS, 107, 6753-6758. doi:10.1073/pnas.0914826107

Young, A.I., Ratner, K.G., \& Fazio, R.H. (2014). Political attitudes bias the mental representation of a presidential candidate's face. Psychological Science.

Yzerbyt, V. Y., Castano, E., Leyens, J. Ph., \& Paladino, M. P. (2000). The primacy of the ingroup : The interplay of entitativity and identification. In W. Stroebe \& M. Hewstone (Eds.), European Review of Social Psychology, 11, 257-295

Yzerbyt, V. Y., Corneille, O., \& Estrada, C. (2001). The interplay of subjective essentialism and entitativity in the formation of stereotypes. Personality and Social Psychology Review, 5, 141-155.

Zaki, J., \& Mitchell, J. P. (2011). Equitable decision making is associated with neural markers of intrinsic value. Proceedings of the National Academy of Sciences, 108(49), 19761-19766.

Zaki, J., \& Mitchell, J. P. (2013). Intuitive Prosociality. Current Directions in Psychological Science, 22(6), 466-470.

Zheng, X., \& Segalowitz, S. J. (2013). Putting a face in its place: in-and out-group membership alters the N170 response. In press at Social cognitive and affective neuroscience.

Zink, C. F., Tong, Y., Chen, Q., Bassett, D. S., Stein, J. L., \& Meyer-Lindenberg, A. (2008). Know your place: neural processing of social hierarchy in humans. Neuron, 58(2), $273-$ 283. 


\section{Footnotes}

Relationship partners (i.e., dyadic partners) can also become strongly integrated with the representation of one's self (Aron, Aron, Tudor, \& Nelson, 1991; Beckes, Coan, \& Hasselmo, 2013). However, dyads differ from groups in several important respects (e.g., dyads are more ephemeral and evoke stronger emotions; several key group phenomena, including coalitions and minority influence, cannot occur in dyads; Levine \& Moreland, 1990; Moreland, Hogg, and Hains, 1994), placing a thorough analysis of dyads outside the scope of the current review. The neuroscience of social relationships is a rapidly growing area of inquiry (see Beckes \& Coan, 2014); exactly how dyadic relationship phenomena relate to intergroup phenomena in the brain is a wide open question. 


\section{Acknowledgments}

The authors gratefully acknowledge the financial support of the Berkman Faculty Development Fund awarded by Carnegie Mellon University to M.C.. Many thanks to members of the Social Perception and Evaluation Lab at New York University and Tatiana Lau for comments on earlier drafts. Special thanks to Lisa Kaggen for assistance preparing this manuscript. 
Table 1. Summary of relevant brain regions and neuroendocrine systems, their associated general functions, and original/updated theories of function from intergroup relations research. Subscripts denote the following: (a) majority subject population (b) minority subject population or (c) majority and/or minority status of subject population was not reported in the study

\begin{tabular}{|c|c|c|c|c|c|}
\hline $\begin{array}{l}\text { Biological } \\
\text { target }\end{array}$ & Task & Moderator & General function & Groups application & Citation \\
\hline \multirow[t]{3}{*}{ amygdala } & $\begin{array}{l}\text { Viewing other-race } \\
\text { faces in Black }^{b} \& \\
\text { White }^{a} \text { participants }\end{array}$ & $\begin{array}{l}\text { Individual differences } \\
\text { correlated with IAT } \\
\text { (Cunningham et al., } \\
\text { 2004) and startle eye } \\
\text { blink (Phelps et al., } \\
\text { 2000) }\end{array}$ & $\begin{array}{l}\text { Fear conditioning; } \\
\text { processing negative } \\
\text { stimuli }\end{array}$ & $\begin{array}{l}\text { Negativity (disgust and fear) } \\
\text { toward stigmatized groups }\end{array}$ & Hart et al., 2000 \\
\hline & $\begin{array}{l}\text { Viewing in-group } \\
\text { faces in a mixed-race } \\
\text { minimal group } \\
\text { paradigm }^{\text {a }}\end{array}$ & & $\begin{array}{l}\text { Segregation of relevant } \\
\text { from irrelevant to } \\
\text { enhance perception of } \\
\text { important stimuli }\end{array}$ & $\begin{array}{l}\text { Responsive to the most } \\
\text { motivationally relevant stimuli } \\
\text { in the absence of other salient } \\
\text { groups (e.g., race) }\end{array}$ & $\begin{array}{l}\text { Van Bavel et al., } \\
2008\end{array}$ \\
\hline & $\begin{array}{l}\text { Playing an interactive } \\
\text { game in an unstable } \\
\text { (vs. stable) hierarchy } \\
\text { elicits greater activity }\end{array}$ & & $\begin{array}{l}\text { Processing social } \\
\text { emotional stimuli; } \\
\text { Threat response }\end{array}$ & $\begin{array}{l}\text { Emotional arousal related to } \\
\text { the possible social hierarchical } \\
\text { consequences of performance }\end{array}$ & Zink et al., 2008 \\
\hline \multirow[t]{3}{*}{$\begin{array}{l}\text { fusiform } \\
\text { gyrus }\end{array}$} & $\begin{array}{l}\text { Viewing own-race } \\
\text { faces in Black }{ }^{\mathrm{b}} \& \\
\text { White }^{\mathrm{a}} \text { participants }\end{array}$ & $\begin{array}{l}\text { Correlated with own- } \\
\text { race bias on recognition } \\
\text { memory task }\end{array}$ & $\begin{array}{l}\text { Processing and } \\
\text { individuating faces; } \\
\text { perceptual expertise }\end{array}$ & $\begin{array}{l}\text { Superior perceptual expertise } \\
\text { with own-race faces may } \\
\text { moderate the own-race bias }\end{array}$ & $\begin{array}{l}\text { Golby et al., } \\
2001\end{array}$ \\
\hline & $\begin{array}{l}\text { Viewing in-group } \\
\text { faces in a mixed-race } \\
\text { minimal group } \\
\text { paradigm }^{\text {a }}\end{array}$ & & $\begin{array}{l}\text { Flexible involvement in } \\
\text { individuation of faces- } \\
\text { motivational relevance }\end{array}$ & $\begin{array}{l}\text { Sensitive to shifts in self- } \\
\text { categorization, aiding } \\
\text { response to motivationally- } \\
\text { relevant faces, regardless of } \\
\text { expertise }\end{array}$ & $\begin{array}{l}\text { Van Bavel et al., } \\
2008\end{array}$ \\
\hline & $\begin{array}{l}\text { Greater recognition } \\
\text { memory for minimal }\end{array}$ & & $\begin{array}{l}\text { Flexible involvement in } \\
\text { individuation of faces- }\end{array}$ & In-group members are & $\begin{array}{l}\text { Van Bavel et al., } \\
2011\end{array}$ \\
\hline
\end{tabular}


groups in- (vs. outgroup) faces ${ }^{a}$ motivational relevance

another in a

competitive condition

mPFC

cooperative

condition) ${ }^{\mathrm{C}}$

Playing an interactive game in an unstable

(vs. stable) hierarchy elicits greater activity ${ }^{a}$

Salience of personal moral standards while competing in a group (independent selfreference task) ${ }^{c}$

Viewing in-group members in a painful situation, in Black participants only

Playing a prisoner's dilemma game with an in-group member ${ }^{c}$

Correlated with willingness to harm competitors

Correlated with ingroup bias in empathic ratings

Correlated with greater report of in-group bias

\section{Mentalizing}

Mentalizing; Person perception

Self-referential processing

Cognitive empathic processing rocessed as individuals more

than out-group members-or:

individuating in-group

members is more automatic

than out-group

Competing with another

requires maintenance of the

perspectives of both self and

Decety et al. others

Social cognition related to the possible social hierarchical

consequences of performance

Zink et al., 2008 (including reputation)

Competing as a group can reduce the salience of one's own moral standards and enable harm

Cikara et al., 2013

In addition to affective empathic processing normally occurring with empathy, regardless of group, extraordinary empathy for one's in-group involves cognitive empathic processing

Mentalizing about an in-group member is facilitated by perceived similarities with 2008 oneself

Mathur et al., 2010

Rilling et al., 


\begin{tabular}{|c|c|c|c|c|c|}
\hline $\begin{array}{l}\text { TPJ } \\
\text { - ITPJ }\end{array}$ & $\begin{array}{l}\text { Viewing same-race } \\
\text { vs. other-race targets' } \\
\text { emotional suffering, in } \\
\text { Koreans }{ }^{a} \text { and } \\
\text { Caucasian } \\
\text { Americans }^{a}\end{array}$ & $\begin{array}{l}\text { Greater activity in } \\
\text { Koreans correlated with } \\
\text { preference for social } \\
\text { hierarchy }\end{array}$ & Mentalizing & $\begin{array}{l}\text { Cultural values may directly } \\
\text { modulate the systems involved } \\
\text { in representing others' mental } \\
\text { states, and in turn, empathic } \\
\text { processing }\end{array}$ & $\begin{array}{l}\text { Cheon et al., } \\
2011\end{array}$ \\
\hline - rTPJ & $\begin{array}{l}\text { During a Prisoner's } \\
\text { Dilemma game with a } \\
\text { minimal groups in- } \\
\text { group member }^{c}\end{array}$ & $\begin{array}{l}\text { Correlated with greater } \\
\text { report of in-group bias }\end{array}$ & Mentalizing & $\begin{array}{l}\text { Mentalizing about an in-group } \\
\text { member is facilitated by } \\
\text { perceived similarities with } \\
\text { oneself }\end{array}$ & $\begin{array}{l}\text { Rilling et al., } \\
2008\end{array}$ \\
\hline \multirow[t]{2}{*}{ OFC } & $\begin{array}{l}\text { Playing a game with } \\
\text { another in a } \\
\text { competitive condition } \\
\text { (as compared with } \\
\text { cooperative } \\
\text { condition) }\end{array}$ & & $\begin{array}{l}\text { Making behavioral } \\
\text { Choices; encoding } \\
\text { relative value }\end{array}$ & $\begin{array}{l}\text { Cooperating with others is } \\
\text { socially rewarding }\end{array}$ & $\begin{array}{l}\text { Decety et al., } \\
2004\end{array}$ \\
\hline & $\begin{array}{l}\text { Choosing to allocate } \\
\text { monetary resources } \\
\text { equitably in a Dictator } \\
\text { game }^{c}\end{array}$ & & Value representation & $\begin{array}{l}\text { Choosing to act pro-socially } \\
\text { has high reward-value }\end{array}$ & $\begin{array}{l}\text { Zaki \& Mitchell, } \\
2011\end{array}$ \\
\hline \multirow[t]{2}{*}{$\begin{array}{l}\text { ventral } \\
\text { striatum }\end{array}$} & $\begin{array}{l}\text { Engaging in mutually } \\
\text { cooperative social } \\
\text { interactions in a } \\
\text { Prisoner's Dilemma } \\
\text { game }^{c}\end{array}$ & & Reward processing & $\begin{array}{l}\text { Engaging in a mutually } \\
\text { cooperative social interaction } \\
\text { has high reward-value }\end{array}$ & $\begin{array}{l}\text { Rilling et al., } \\
2002\end{array}$ \\
\hline & $\begin{array}{l}\text { Distributing monetary } \\
\text { resource to self and } \\
\text { others }^{c}\end{array}$ & & Reward processing & $\begin{array}{l}\text { Reward signals are modulated } \\
\text { by social factors (e.g., } \\
\text { inequality-averse preferences) }\end{array}$ & $\begin{array}{l}\text { Tricomi et al., } \\
2010\end{array}$ \\
\hline
\end{tabular}


Seeing the pain of a unfair confederate in a Prisoner's Dilemma game $^{\mathrm{c}}$

Viewing higher-

ranked compared to

lower-ranked

individuals (compared

to oneself) ${ }^{a}$

Watching rival teams

failing to score

(correlates with

reported pleasure $)^{\mathrm{c}}$

Watching a rival

team's fan experience pain

Administering

dorsal punishments that

striatum

payoff ${ }^{\mathrm{c}}$

Correlated with

expressed desire for

revenge

Low SES show greater activity to lower status targets; high SES

replicate original

findings (Ly et al., 2011)

Effects holds even against a lower-ranked team

\section{Correlated with a} decreased willingness to accept a proportion of the fan's pain

Correlated with greater will to incur a self-cost in order to punish
Reward processing

Serving justice is rewarding

Singer et al., 2006

Reward salience; valuation

Valuation; motivation

Increased reward value of outgroup failure may contribute to counter-empathic responses

Cikara et al., 2011

Reward processing

Increased reward value of outgroup failure may contribute to counter-empathic responses

Hein et al., 2010

Reward processing

Punishing a norm violation is rewarding

DeQuervain et al., 2004
During comparison of people who are closer

to one another in a

social hierarchy ${ }^{\mathrm{a}}$
Representation of scalar magnitudes (processing higher vs. lower numerical values)
Social status inference recruits regions involved in numerical processing
Chiao et al., 2008 cortical Viewing racial ingroup

midline members in painful

situations, in African

subsyste American

m of DMN participants ${ }^{b}$
Correlated with greater racial identification

Self-referential
processing (e.g.,
introspection, personal
significance, affective
processing)

Highly identified minority group members may empathize by accessing their own feelings and having a personal, Mathur et al. 2012 


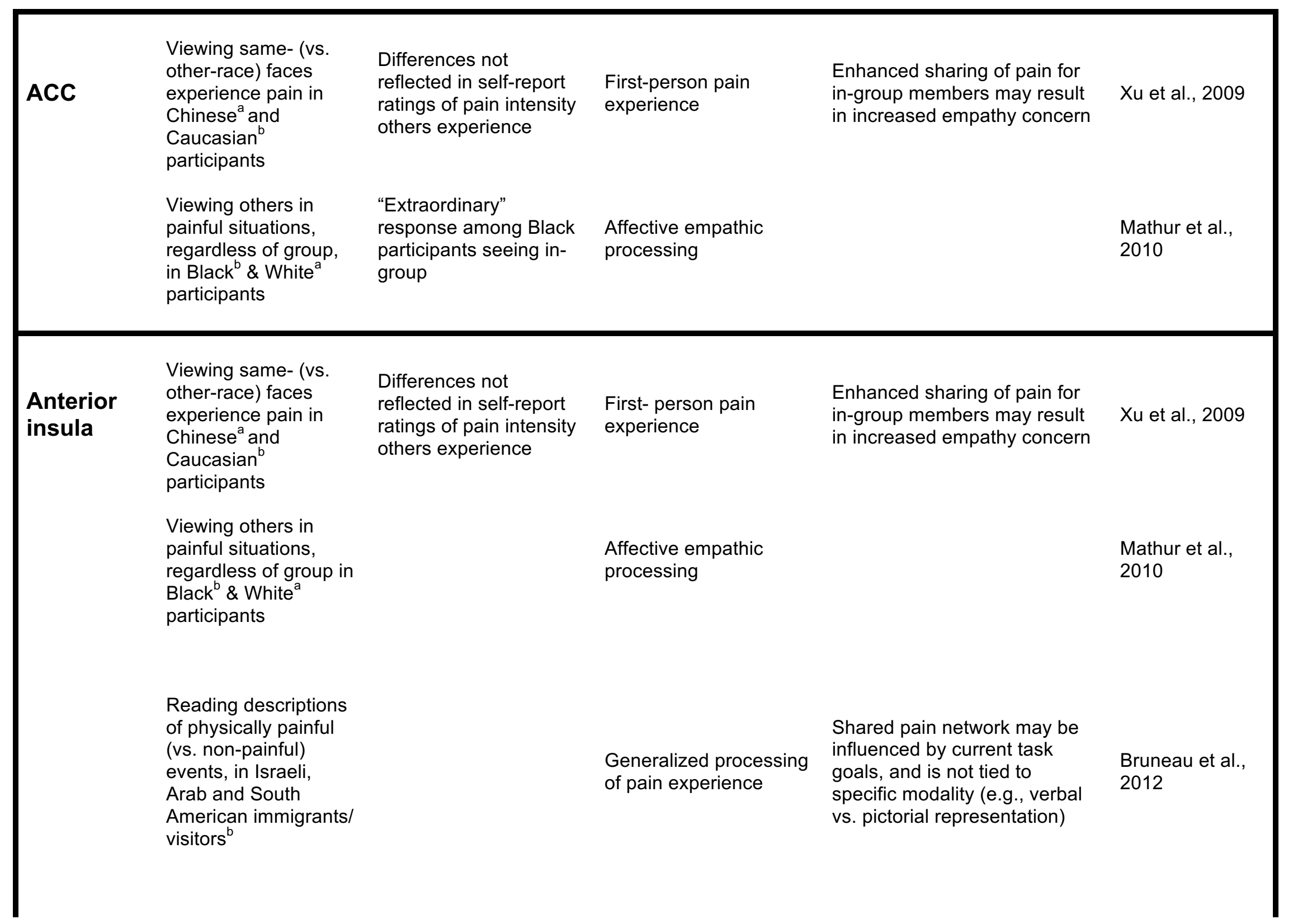


Viewing competitive, high-status targets good fortunes ${ }^{c}$
Correlated with willingness to harm competitive high-status targets
Shared neural circuit for pain

Facilitates affiliative motivation and prosocial behavior

Facilitates "tend and defend" behavior toward the in-group in particular
Shared pain network is

influenced by group

distinctions and status, with Cikara \& Fiske potential effects on 2011b

(e.g., harm)

May help to reduce conflict

Kosfeld et al. 2005

Supports parochial behavior that undergirds several De Dreu et al. 2010

Playing trust game $e^{a, b}$

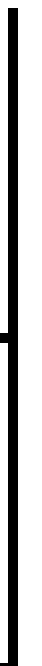


Figure 1. Anatomical images of several key brain regions associated with group categorization and evaluation, functional relations between groups, empathy, and pro-social and anti-social behavior. As such, this figure is meant to serve as a guide to the location of various regions we reference frequently (not to represent a neural circuit supporting one process in particular). $\mathrm{mPFC}=$ medial prefrontal cortex. $\mathrm{OFC}=$ orbitofrontal cortex.
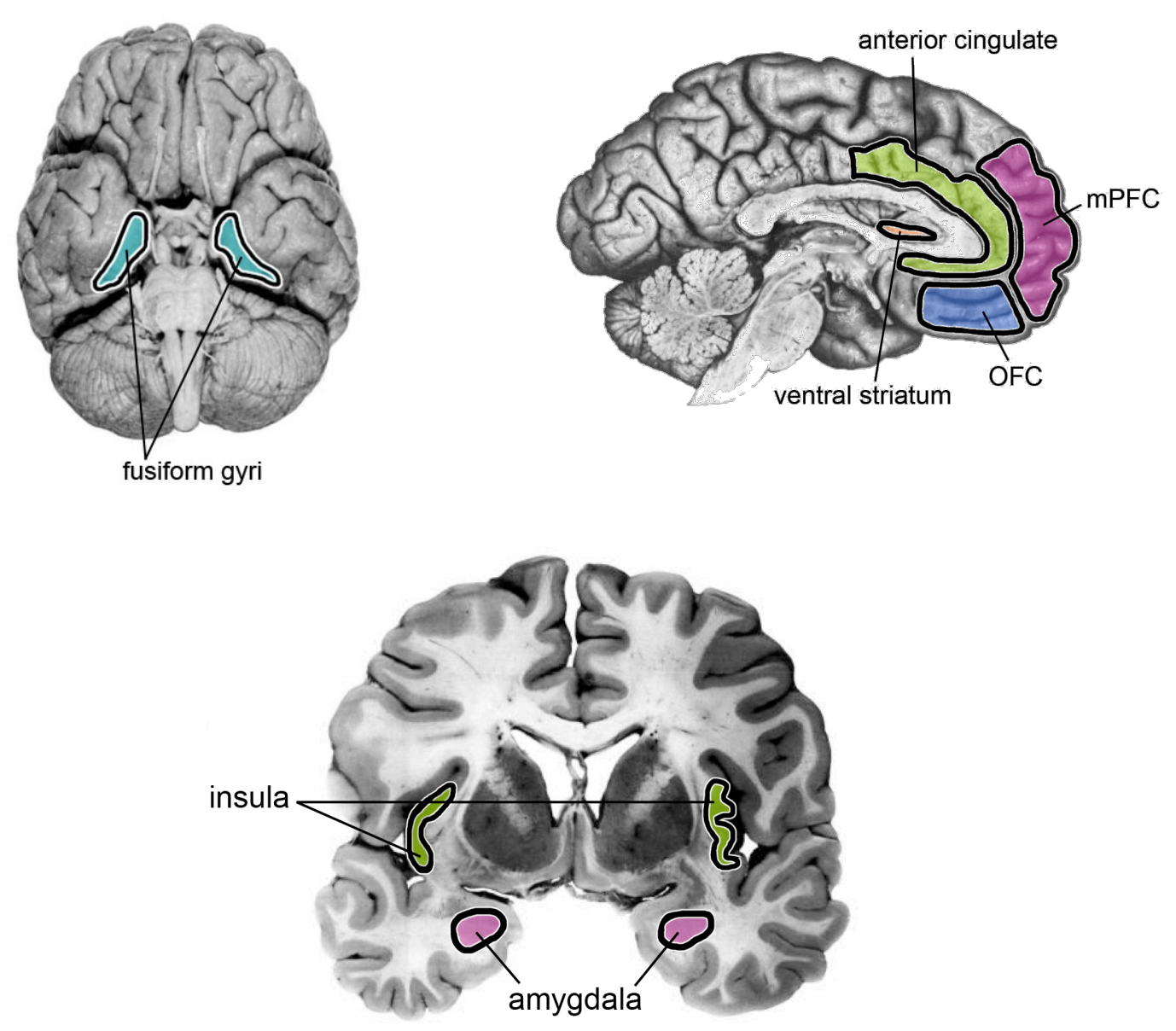